\title{
E essa aranha aí e esse raio de lua
}

Entrevista com Livia Flores realizada no ateliê da artista, no Rio de Janeiro, em 11 de outubro de 2018. Entrevistadores: Analu Cunha, Fernanda Pequeno, João Modé, João Paulo Quintella e Maria Moreira. Transcrição: Marcia Milome e Fernanda Pequeno.

Fernanda Pequeno: Em nome da Concinnitas e do Instituto de Artes da UERJ, eu gostaria de agradecer por você ter aceitado ser entrevistada e também a todos os participantes dessa conversa. Eu queria que você começasse falando um pouco sobre a sua ida para a Alemanha, que cenário existia no Brasil, pensando não só sobre o que você estava produzindo, mas também sobre o que havia em termos de publicações, como eram as instituições, os artistas e as produções. E depois, gostaria de saber o que acontece quando você retorna: o que mudou no seu trabalho e como esse cenário estava diferente?

Livia Flores: Então, eu que agradeço, me sinto muito honrada sendo entrevistada por vocês e para a Concinnitas.

Eu fui para Alemanha em 1984, tinha vinte e quatro anos e uma graduação em desenho industrial na Esdi/UERJ. A minha formação em arte se deu por vias um pouco laterais, não frequentei o Parque Lage, por exemplo, mas a Escolinha de Arte do Brasil onde fazia xilogravura com José Altino. Depois, um grupo de professores ${ }^{1}$ saiu de lá e fundou um lugar de encontros e cursos, lá eu conheci o Paulo Garcez, que fazia acompanhamento de trabalhos. Meus colegas eram Brígida Baltar, Chico Fortunato, Adriano Mangiavacchi, entre outros. Fiz a primeira individual na Macunaíma em 83, mostrando desenhos e colagens. Aí soube de uma bolsa de estudos para Alemanha. Apliquei e fui. Estava de saco cheio daqui. Sem saber alemão, sem saber nada.

João Modé: Mas você não participou da Geração Oitenta?

LF: Sim, mas eu já não estava mais aqui. Eu deixei os trabalhos e fui.

Analu Cunha: Aí você foi para Alemanha, foi estudar o que especificamente?

LF: Fiquei os primeiros seis meses estudando alemão e depois fui para a Academia de Artes de Düsseldorf.

JM: Aonde o Joseph Beuys dava aula?

\footnotetext{
${ }^{1}$ Marília Rodrigues, Maria Luiza Saddi, Ana Cristina Pereira de Almeida, Maria Tornaghi, Juca Pessoa, Sheila Dain.
}

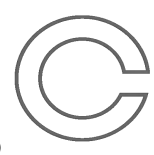


LF: Exatamente! Eu o vi algumas poucas vezes na Academia, ele já não dava aulas há muito tempo. ${ }^{2}$ Eu cheguei no final de 1984, ele morreu em 86 .

João Paulo Quintella: E o Beuys foi o motivo? Era um momento em que a Alemanha não era tão aberta como hoje.

\section{JM: Aquela linguinha fácil! (risos)}

LF: Uma escolha muito tranquila (risos). Loucura, né!? Choque total! Ainda mais nos anos oitenta, quando eu cheguei.

\section{AC: Era Guerra Fria ainda. Muro...}

LF: A primeira cidade foi Mannheim, onde fiz o curso de alemão. Fui morar em um lugar que tinha um campo militar americano de um lado e do outro lado um bunker. Foi como um mergulho em uma piscina vazia! Düsseldorf era mais legal mas para uma carioca de vinte e poucos anos, acostumada com praia, posto 9, foi uma empreitada. E aí voltei nos anos noventa, em 93. Foi outro choque!

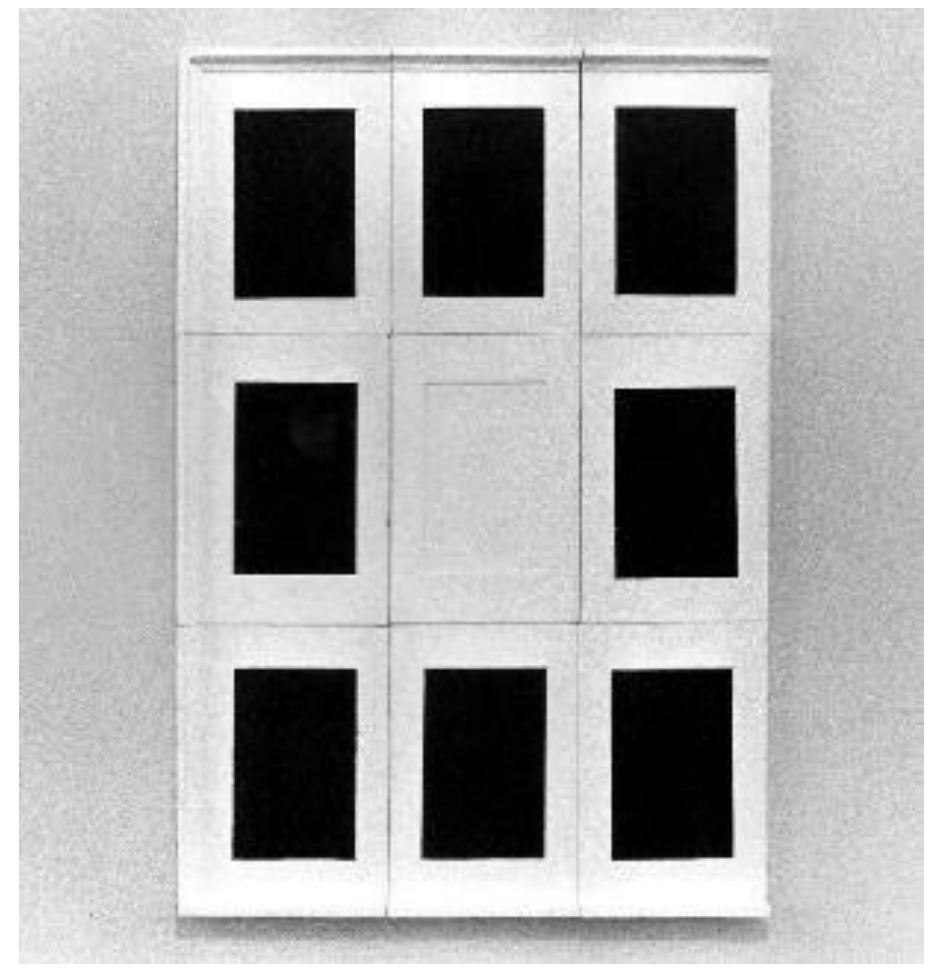

Pedras (Candelária), 1993

Gesso e papel carbono $98 \times 68 \times 4 \mathrm{~cm}$

Foto: Vicente de Mello

\footnotetext{
${ }^{2}$ No começo dos anos 1970, a admissão irrestrita de estudantes em sua classe provocou atritos institucionais que culminaram com sua exoneração, contestada por Beuys em longo processo contra o Estado alemão, que ao final lhe deu ganho de causa. $\mathrm{O}$ episódio está ligado à criação da F.I.U. (Free International University) e Beuys nunca mais voltou ao ensino formal, objeto de críticas veementes de sua parte.
} 
AC: Por que você decidiu voltar? Você terminou o curso lá, era uma graduação, um mestrado?

LF: Não, lá é um pouco diferente o sistema. Na Academia de Artes, você podia optar por fazer Freie Kunst, que é Arte Livre, ou faz Kunstwissenschaft, que é Ciência da Arte, Sociologia, História da Arte, etc.. Eu optei por Freie Kunst. E aí você não recebe nenhum diploma, vai pra Academia, trabalha sob orientação de um professor e é isso, o máximo que você consegue é uma Carta de Aluno Mestre.

Morei em Düsseldorf e depois mudei para Colônia, que é bem perto, meia hora mais ou menos. É uma cidade com uma quantidade gigantesca de galerias. Galerias importantes, já nos anos noventa.

JM: Você tinha contato com o Antônio Dias?

LF: Tinha, ele morava pertinho, em Colônia. Eu fui para Colônia em 1989, um pouco depois da queda do muro de Berlim. Ele e outros artistas brasileiros chegaram por aí, por volta de 1990. Durante uns dois anos, eu dividi um atelier com Carlito Carvalhosa e com José Spaniol. Foi uma delícia!

MM: Como foi a experiência por lá, eu sei que isso já está na entrevista do livro, mas eu fiquei curiosa em saber sobre esse arco. Porque na época que você entrou no sistema acadêmico como artista, ainda estava começando a aflorar essa coisa dos artistas fazerem pós-graduação, ter mais essa estrutura acadêmica como campo de ação. Quando você volta, me lembro de você falando assim: "eu só penso em bolsa, não estou interessada em edital".

\section{LF: Fui bolsista profissional! Profissão: bolsista.}

MM: Exato! Entra no sistema acadêmico, aqui também, e tem sua vida acadêmica, e eu gostaria de entender esse arco. Eu acho que nós vivemos um momento, nas artes, que é meio como o momento das ciências humanas frente às ciências duras, exatas, na passagem do século XIX para o XX. Estamos constituindo as nossas formas de legitimação, que são de acordo e adequadas ao campo de conhecimento que a gente constrói. E aí me interessa saber, como é que esses procedimentos migram da feitura para o ensino, da experiência do ateliê individual para a experiência do ateliê coletivo, do ateliê para a sala de aula. Como é que se dá esse arco, para entender as especificidades desses trabalhos que a gente está fazendo agora, de constituir as formas de legitimação desse saber. Eu lembro que do circuito da gente, você foi uma das primeiras que estava tendo essa experiência acadêmica, antes da coisa se expandir.

LF: Vamos por partes. Essa experiência acadêmica na Alemanha, eu nem chamaria de acadêmica, enfim, é claro que era uma Academia, uma Escola Superior de Artes, mas com uma estrutura bem diferente do que a gente entende hoje por estrutura acadêmica em Arte. Lá era ainda derivada do modo de formação tradicional de um artista, que trabalha sob a orientação de outro artista, e ponto. Não tem que escrever, não tem prova, não tem nada. Você vai lá todo dia, eu tinha um pedaço de parede, botava lá uma tela e pintava, ou então eu ia para uma das oficinas da Academia: gesso, pedra, madeira, e ficava trabalhando na oficina. Então era assim, simplesmente um dia de trabalho de ateliê, de prática de ateliê.

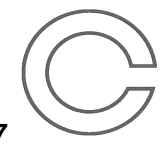


JM: Mas tinha matérias teóricas também?

LF: Não obrigatórias para arte livre. Eu até fiz uma ou outra, é um modelo muito tradicional de aula, em que o professor prepara lá sua pesquisa e durante um semestre, vai ler a pesquisa, compartilhar com os alunos.

JPQ: Isso parece ir ao encontro do que a Maria comentou. Poderíamos localizar uma espécie de migração das práticas artísticas e do pensamento artístico para a Academia, onde os artistas ainda não estavam tão presentes como hoje. Aqui no Brasil você já encontrava os artistas na academia?

MM: Eu acho que a nível de graduação. E mesmo assim, tinha toda uma geração que tinha circunavegado a graduação específica em artes e já estava dentro do circuito, tinha feito outra graduação.

AC: A gente fez. Em meados dos anos oitenta surge a pós em Arte e arquitetura no Brasil, na PUC, que muitos de nós fizemos. E a EBA, que já existia desde o século 19, ainda que não formasse artistas-pesquisadores.

JM: Eu e Analu fizemos Belas Artes na UFRJ, mas fizemos Programação Visual.

LF: Eu não quis fazer Belas Artes, porque sei lá, não tinha interesse. Achava que desenho industrial me daria mais base profissional.

MM: Havia uma rejeição para com essa formação.

JM: Os cursos eram caretas. Não te motivavam. Todo mundo era artista já, todos tinham um trabalho, uma pesquisa, mas ninguém fazia os cursos regulares que eram divididos em pintura, escultura, gravura, cenografia...

JPQ: Parece que o ensino acadêmico em artes ainda estava muito voltado para o fazer, enquanto o pensamento sobre artes talvez ainda não circulasse tanto pela Academia. Mesmo na Alemanha, as menções que você faz às aulas são, em sua maioria, práticas. Mas, pelo que entendi, uma série de textos eram trazidos pelos professores, ou seja, não havia uma ementa a ser debatida e sim tópicos, exercícios.

LF: O professor pesquisava na sua casa, produzia um texto e ia para a aula ler. Tanto que aula era Vorlesung (ler diante de).

AC: Na Europa é assim até hoje. Na França é assim direto, professor lê um texto em sala de aula.

MM: O que você está falando são duas coisas, eu não chamaria o que você estava fazendo de aula, era uma prática de ateliê e vinha um professor de vez em quando e conversava com você. Era alguém que te acompanhava, do início ao fim da sua estadia por lá. É quase como emular a prática de ateliê tradicional.

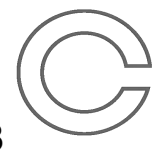


LF: Sim, exatamente essa é a ideia da Carta de Aluno Mestre (Meisterschülerbrief), o aluno que é elevado à condição de mestre pelo seu mestre. E aí, quando eu voltei em 1996, fui para Escola de Comunicação da UFRJ fazer mestrado em Comunicação e Cultura porque alguns amigos tinham feito mestrado lá: Ricardo Basbaum, Cristina Salgado.

Naquele momento o Zílio tinha acabado de abrir a pós-graduação em Linguagens Visuais no Fundão, então isso era recente. Ele estava vindo da PUC, convidado a abrir essa linha teóricoprática para artistas na UFRJ. Acho que aqui no Rio foi a primeira dentro de uma universidade. $\mathrm{Na} \mathrm{ECO}$, o mestrado era totalmente teórico.

$\mathrm{AC}$ : Quem te orientou?

LF: Rogério Luz, que é artista também. Um professor maravilhoso!

Só fui fazer doutorado em 2003. Porque eu comecei a dar aula na Cândido Mendes, e aí as minhas colegas Regina de Paula e Zalinda Cartaxo ficavam falando: você tem que fazer doutorado, artista no Brasil morre de fome. E eu acabei indo.

JM: A gente fez algumas disciplinas juntos lá no Fundão. Era bom!

LF: Lembro da sua defesa, aquela ocupação do galpão maravilhosa!

FP: Você sempre quis ser professora, Livia?

LF: Não.

FP: Como é que isso se deu? Porque a cronologia do livro fala que no comecinho dos anos oitenta você atuou com Arte e Educação, no âmbito da Escolinha da Arte no Brasil, como é que foi?

LF: Foi a partir de um curso de Arte e Educação. Eu trabalhei num projeto da Secretaria de Cultura, era um projeto na rua, em praças. Saía um ônibus ou Kombi cheia e a gente ia para lugares periféricos, às vezes trabalhando em escolas também. Foi bem legal, por volta dos anos 80, 81, 79, por aí.

MM: Isso te deu a experiência da cidade?

LF: Sim, eu acho que sim.

MM: Você tem isso, deslocamento como matéria do seu trabalho.

LF: Sim. Sempre fui muito atenta à cidade. Gosto de entender; entender não, você não entende uma cidade, mas gosto de tentar me localizar e procurar perceber os fluxos dela. Porque o Rio de Janeiro tem uma vida na rua muito intensa. Sempre teve.

AC: Engraçado, falando da cidade, você fez um gesto e o seu trabalho tem uma horizontalidade. Mesmo os filmes têm um plongée. Presta atenção: não tem céu no seu trabalho e, quando tem, é

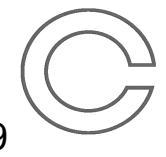


um céu refletido, uma poça. Mesmo em Feliz ano novo, a foto é de cima para baixo. Tem uma coisa de uma cidade, que acontece na rua, nesses trajetos. O que você acha disso, já pensou a respeito?

LF: Não, nunca tinha me ocorrido. É, mas de fato, os movimentos que eu costumo fazer, que eu gosto de fazer, são deslocamentos horizontais e talvez em busca de um ponto de vista meio que de fora da cidade. Deslocamentos periféricos. Pão de Açúcar, cartão postal, só se for invertido, só de cabeça para baixo.

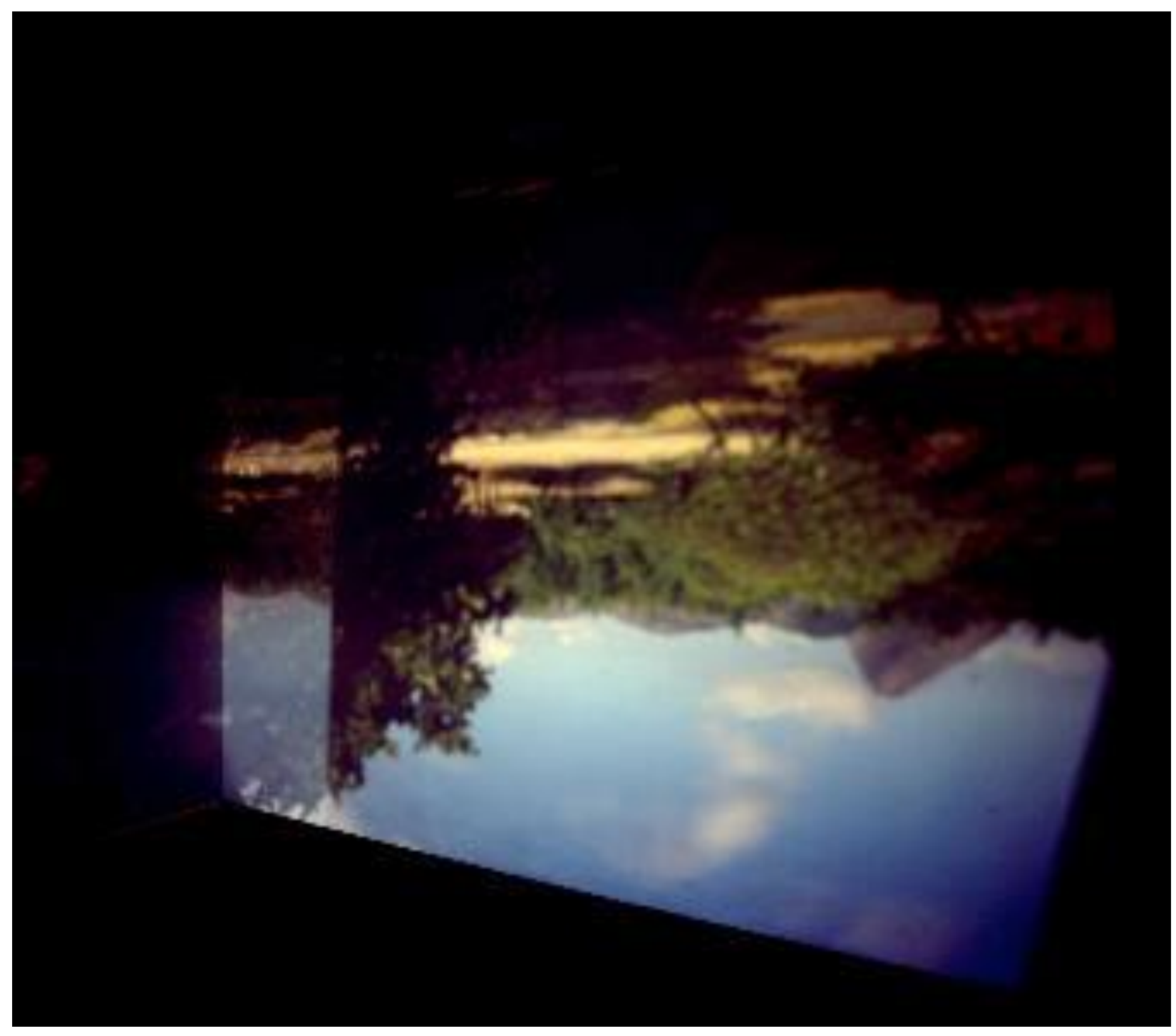

Fundos, 2002

Instalação, câmera obscura Mostra Rio Arte, MAM/Rio

Foto: Beto Felício 
JM: Falando disso, eu me lembrei daquele trabalho que você tinha pensado que não sei se chegou a ir pra frente, você mostrou lá no Fundão, que era aquela avenida no caminho pra casa da sua mãe e que estava mudando o tempo inteiro, lembra disso? E eu fiquei pensando que tem uma coisa de tempo também no trabalho, na escolha dos materiais, que são entranhados de tempo, na forma como você também monta e às vezes já com uma situação de um desequilíbrio, de um acúmulo, que também é uma coisa temporal. Vou perguntar igual à Analu, o que você tem a falar sobre isso? O quanto que o tempo é importante, assim, na escolha do prato que fica girando, quebrado. Tem um comentário do tempo, me parece. Primeiro eu queria saber desse trabalho, do filme.

LF: Esse é o Passa batido mas não despercebido, que virou uma instalação que eu mostrei no MAC Niterói em 2010, cinco anos depois de ter iniciado aquele experimento. Em 2010 fiz novas varreduras. Porque a ideia era fazer varreduras periódicas da Estrada do Rio Morto, aquele lugar sempre me fascinou. Era o que eu chamava de rastreamento do rio morto. Eu colocava uma câmera em cada uma das janelas do carro, ia e voltava percorrendo toda a extensão da estrada.

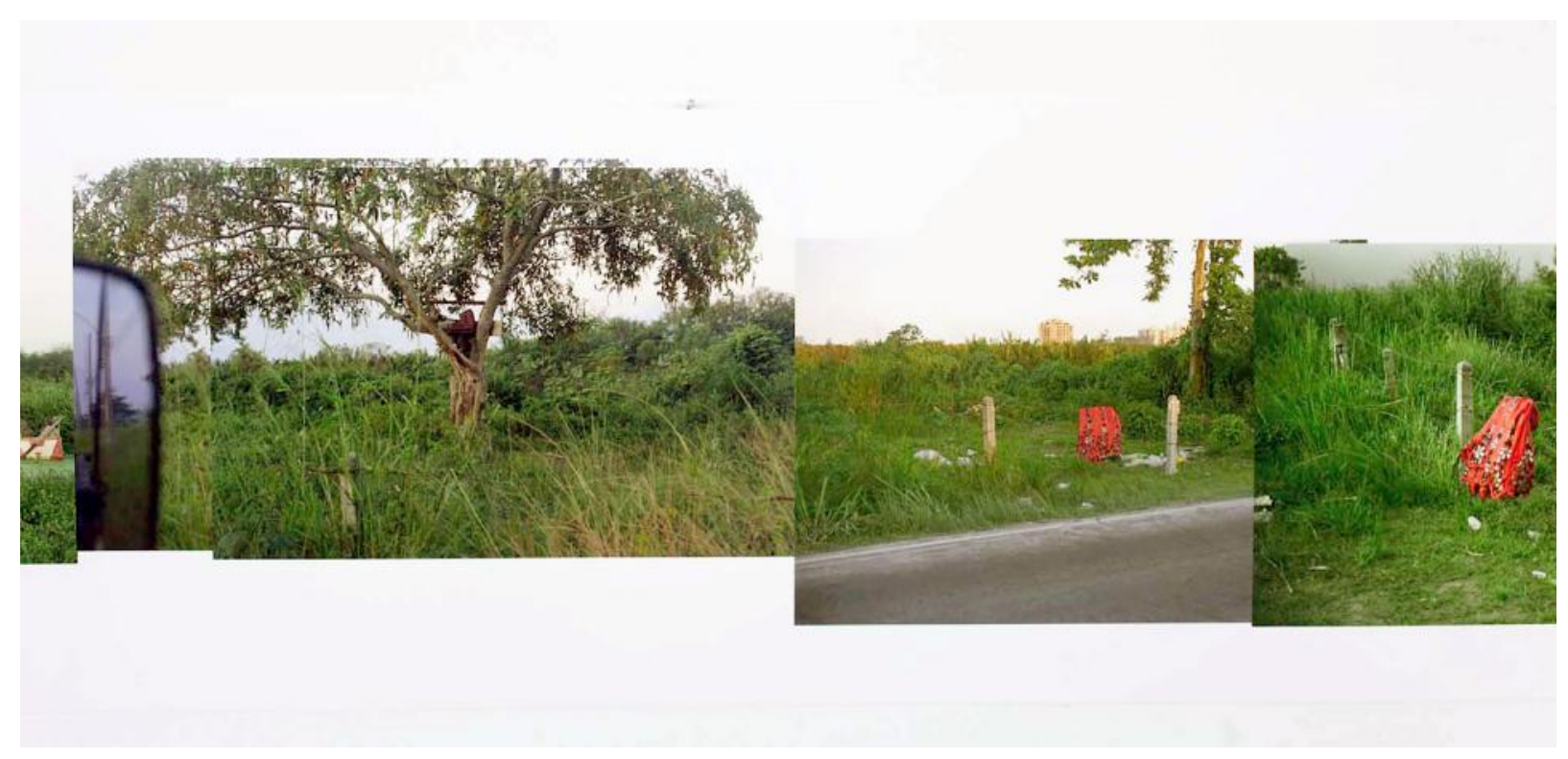

Passa batido mas não despercebido, 2005-2010 (detalhe)

Impressão fotográfica, 22 x $590 \mathrm{~cm}$

Foto: Pat Kilgore

AC: Esse nome é ótimo.

LF: Sim, começa pelo nome.

JM: Livia, você não tem ideia de continuar esse trabalho? Você acha que ele terminou?

LF: Tenho, toda vez que passo por lá, eu digo: "tenho que fazer de novo". Já está completamente diferente, cheio de casas, condomínios.

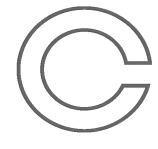


JM: Não são duas telas? E aí, como é que você percebe que você está no mesmo lugar? É isso que queria entender, são essas duplas que são projetadas juntas, é isso?

LF: Você não entende exatamente que está no mesmo lugar, mas tem alguns obstáculos, alguns quebra-molas, tem uma hora que você passa embaixo de um viaduto, são pequenos momentos onde as coisas se juntam e que eu utilizei para sincronizar os dois lados da paisagem, a janela que dá para o canal do Rio Morto e a outra que dá para a terra, para as construções.

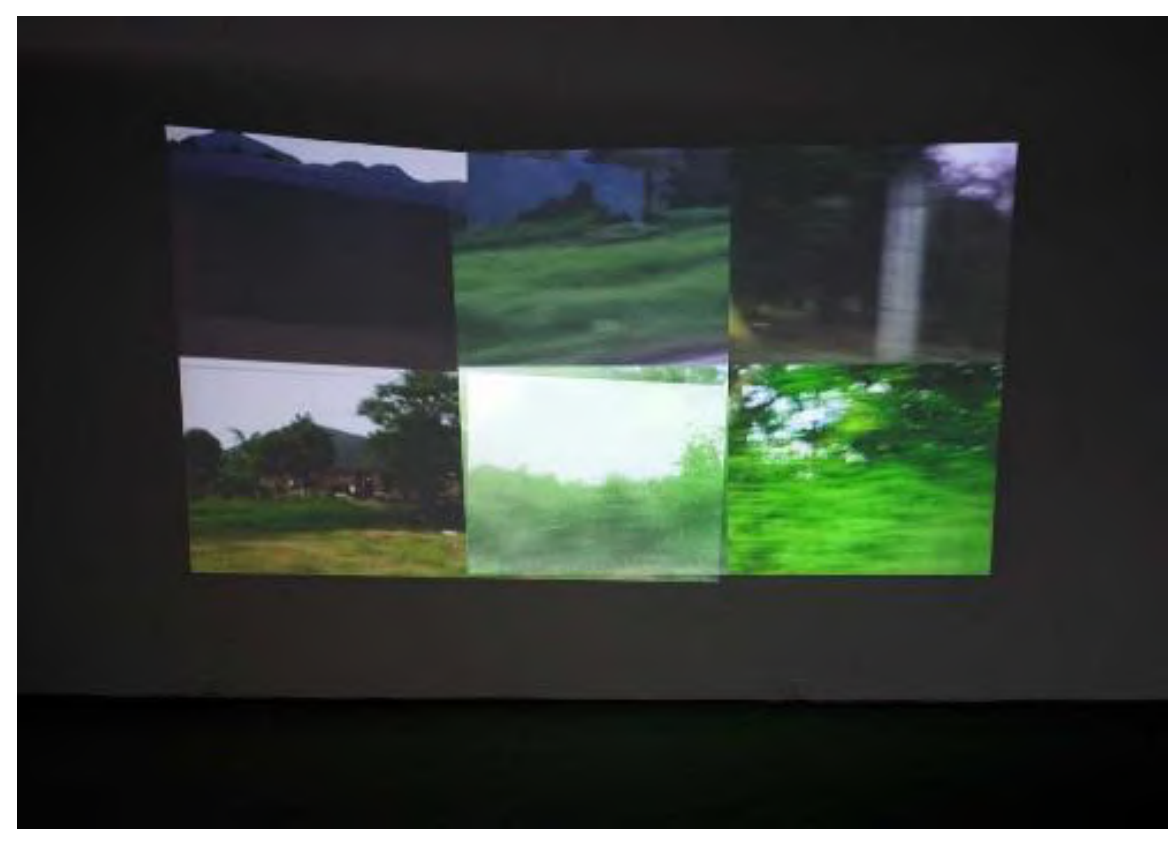

Rastreamento do rio morto, 2010

Videoinstalação

Tempo-matéria, Museu de Arte

Contemporânea de Niterói

Foto: Pat Kilgore

JPQ: Como essas percepções vão entrando no trabalho é algo muito singular. Essa lógica da experiência, do que você está atravessando, é um conceito fundamental para pensar o seu trabalho. Não é necessariamente algo que vai ser anunciado, demarcado ou previsto, não é factual. Existe essa confusão com a ideia de experiência hoje, uma confusão entre experiência e informação. Informar aquilo que vai acontecer não garante o acontecimento, ou seja, não garante que algo nos toque de alguma maneira. Bondía ${ }^{3}$ diz que a experiência não é simplesmente o que acontece mas sim aquilo que nos acontece. Experimentamos o mundo fora de uma lógica magnânima, do evento monumental. O que de fato "nos acontece" é de uma ordem muito mais íntima e cotidiana. Essa escala do acontecimento é fundamental para o seu trabalho e ela fica muito aparente já no título Passa batido mas não despercebido.

LF: O próprio título vem da paisagem. Esse título era um grafite escrito em algum ponto desse caminho. Não é um título que eu inventei ou pensei, ele estava aderido a essa paisagem. No movimento de fotografar, além de gravar em vídeo, nessa ação de percorrer, porque é uma estrada

\footnotetext{
${ }^{3}$ BONDÍA, Jorge Larrosa. "Notas sobre a experiência e o saber de experiência". In Revista Brasileira de Educação [online]. No 19, jan/ fev/ mar 2002. Disponível em: http:/www.scielo.br/pdf/rbedu/n19/n19a02.pdf
} 
bastante longa, então são duas maneiras completamente diferentes de transitar por ali. A pé, você vai começando a perceber detalhes.

MM: As fotos você tira a pé e filma de carro?

LF: Filmo de carro e fotografo a pé. Por exemplo, aí você vê numa árvore o lugar de um vigia e aí você encontra um vestido pendurado na cerca.

(Folheiam o livro Livia Flores, coleção ARTE BRA, publicado pela Produtora Automática) ${ }^{4}$.

JM: Difícil mostrar esse trabalho em livro.

AC: São oito projeções ou oito janelas?

LF: Oito janelas (duas projeções, cada uma com dois pares de janelas), sendo que no meio há uma superposição. Aí você percebe o movimento. Esse trajeto ganha expressão na própria impressão das fotografias, nos cinco ou seis metros que você como espectador também percorre.

FP: Um travelling? O travelling na fotografia.

MM: O travelling no corpo do observador.

JM: Isso aqui é um trechinho dela, então? (Apontando para o livro). São vários cortes, é o somatório de fotos. Não é uma $180^{\circ}$. Entendi.

AC: É porque elas são desniveladas.

LF: Fui tentando encaixar.

AC: O horizonte?

LF: Mais ou menos, para ter uma ideia de horizonte, manter um certo nível.

MM: Isso aponta para uma coisa que eu acho central no seu trabalho, acho que você tem uma espécie de uma vontade de acolhimento amoroso da multiplicidade do mundo. O gesto que a Analu falou, na horizontal, as palavras que você usa - um rastreamento —, são essa vontade de acolher a multiplicidade do mundo.

LF: Sim, acho que tem isso mesmo. "A cidade de tudo", como diz o Calvino.

AC: Qual era a sua cidade preferida?

\footnotetext{
${ }^{4}$ Disponível em: http://www.automatica.art.br/livros/artebra liviaflores2.pdf
} 
LF: Isso não está no Cidades invisíveis, está em outro livro que li quando estava escrevendo a tese. Um livro que tem a ver com Tarô, com jogo.

AC: É O castelo dos destinos cruzados?

LF: Exatamente esse.

MM: E o Tarô também é isso, é um dispositivo para acolher toda a diversidade do espectro humano, das emoções, traumas.

LF: Essa coisa do acaso que me agrada tanto.

JPQ: Essa ideia de acolher nos mostra que você, ou a gente, está suscetível a essa experiência do cotidiano.

LF: Eu acho que isso vem muito da experiência do filme. Porque é essa coisa, é um momento.

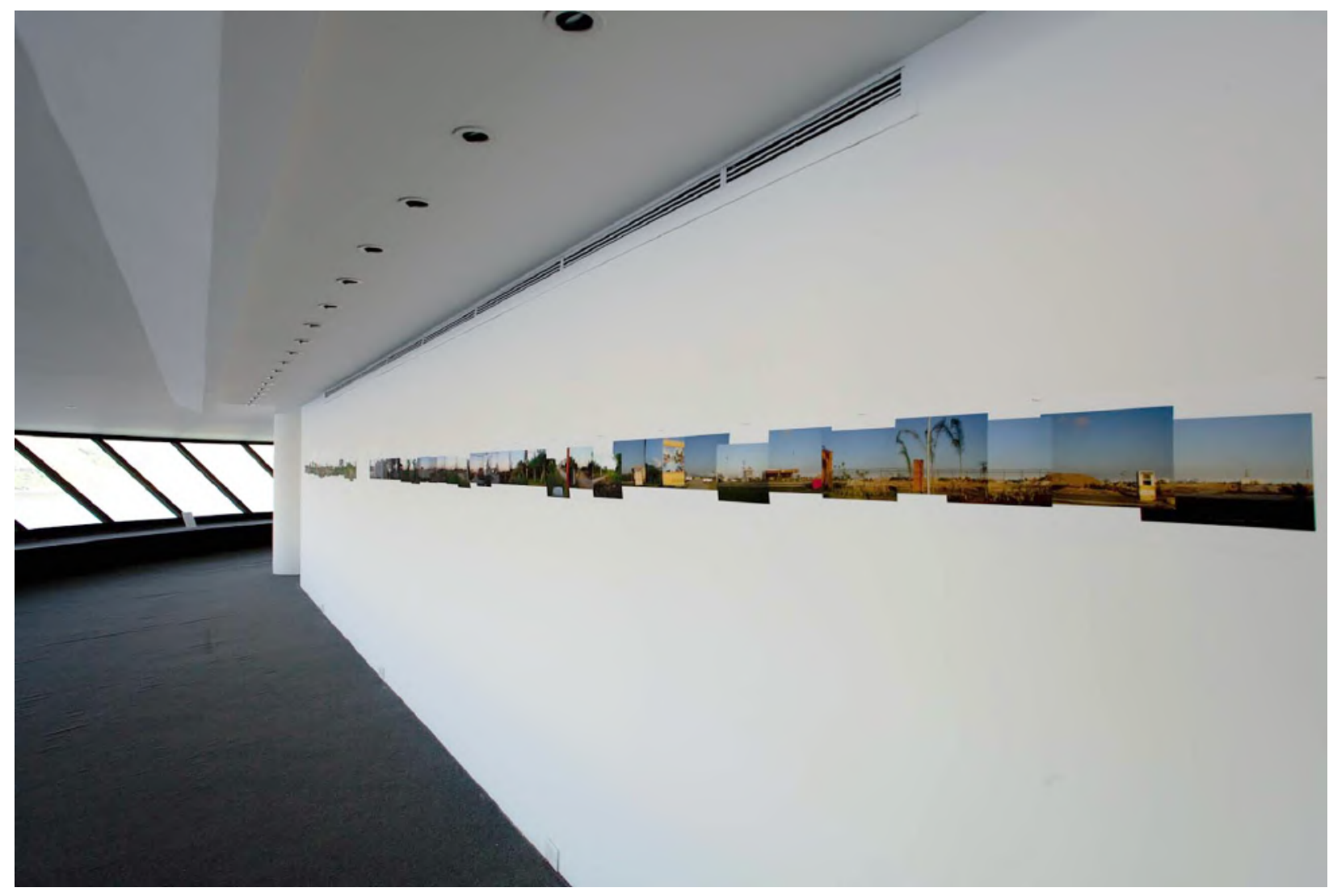

Passa batido mas não despercebido, 2010

Tempo-matéria, Museu de Arte Contemporânea de Niterói Impressões fotográficas

Foto: Pat Kilgore 
Antes de fazer esse trabalho, eu trabalhava com filme, película mesmo. Você tem três minutos e aí é tudo que entra nesses três minutos enquanto você está com a câmera ligada. Não dá muito para escolher, você escolhe, mas sempre vem mais coisa do que você imaginava.

AC: Engraçado você falar isso! Essa coisa do escolher. Porque o seu trabalho, assim, ele percorre zonas do invisível, do invisibilizado, do infrafino, da fresta, é um trabalho antifálico.

\section{LF: Adorei o antifálico!}

AC: Não é monumental. Não tem esse olhar objetivo.

MM: Mas você pinça coisas, tem abertura para acolher e de repente alguma coisa, que eu chamo a marca de intensidade, alguma coisa marca ali como o foco de intensidade. Você vai lá e colhe dando esse recorte da intensidade, por exemplo, esse vestido.

LF: É, tem um treinamento na observação, de você andar e ir reparando nas coisas. Talvez até voltando para a questão do tempo, que eu acabei não respondendo, o tempo é importante para dar tempo das repetições acontecerem, das diferenças serem percebidas, acho que esse trabalho é bem emblemático disso. O mesmo trajeto e as diferenças, que é o que me interessa, os acontecimentos, os micro acontecimentos nesse mesmo trajeto.

JPQ: Me parece que tempo e observação estão interligados no que a Maria Moreira chamou de marca de intensidade.

MM: Que de repente não é instantânea, porque ela fala: “o percurso se repete várias vezes”, então é algo que permanece na memória. No momento da captura, se configura a intensidade, mesmo que demore um certo período para subir para a consciência. E você se dispõe a retornar, que é um modo de você lidar com a multiplicidade do mundo, quando você cria um procedimento de se expor repetidas vezes a um território e depois você retorna ao encontro daquilo que permanece... É uma marca de intensidade cuja conscientização da intensidade não aflora imediatamente, por isso que você se expõe várias vezes até...

JPQ: Essa marca da intensidade aparece sem que ela seja um objetivo. Não há uma procura por ela e, mesmo quando ela aparece, não lhe é atribuída centralidade.

MM: Ela se expõe. Como se fosse uma superfície sensível. Ela se expõe a um agente X, como a gravura, até que ele faça uma marca, mas não é um trabalho de atenção a priori. É uma atenção que é feita através da acumulação da prática, não de uma intenção objetiva. Quando você tem uma prática que se acumula em certos mecanismos de captura, procedimentos de captura, e quando você se dispõe a retornar ao lugar, as coisas estão ligadas, esses mecanismos estão ligados, e independem de uma intenção.

LF: Sim! Nesse caso é bem claro, tem um certo dispositivo, tem uma rua que vira dispositivo, uma rua escolhida. Um lugar para essas idas e vindas, podia fazer isso todos os dias, poderia pegar a câmera e andar por ela todos os dias, teria um arquivo imenso de acontecimentos.

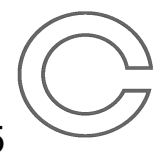




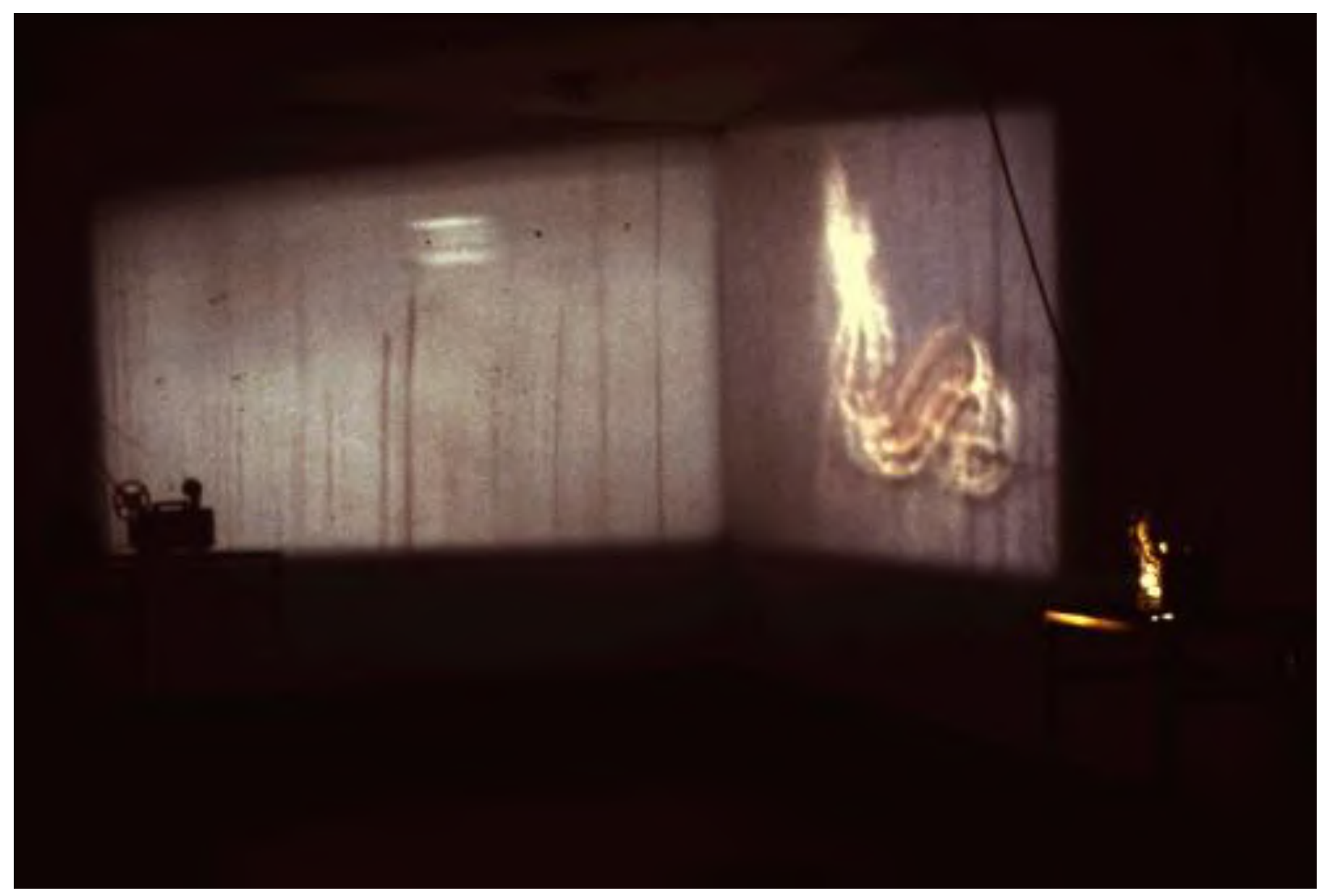

Instalação com filmes super-8 (rio morto/terra encantada/náufrago/distâncias irmãs/ímãs), 1999

8 projetores, diagrama sobre parede

Galeria Candido Portinari, UERJ

Foto: Wilton Montenegro

JM: A cobra, a poça, tudo isso é nesse lugar também?

LF: É. As cobras, o vestido... são trabalhos diferentes realizados em épocas distintas, no mesmo lugar.

JM: Falando em tempo, aquela exposição da UERJ foi quando?

LF: Foi em $1999^{5}$.

JM: O que eu queria falar era na forma como você mostrava os filmes. Eram loopings que você mostrava a extensão do filme inteiro. Era tão lindo aquilo! Que reforçava essa ideia de cinema com aquela luz, que a gente está distante disso agora, tão poético como aquilo era mostrado. Tem essa coisa do tempo também, talvez por ser em looping. Eu achava aquela exposição muito potente.

\footnotetext{
${ }^{5}$ Exposição individual realizada na Galeria Candido Portinari/ Uerj. Instalação com projetores e filmes super-8.
} 
AC: Eu me lembrei do $\tilde{A} O$.

LF: O $\tilde{A O}$ foi meu deslumbre total, quando eu vi aquilo, acho que eu não era nem artista.

JM: $\tilde{A} O$ é aquele filme do Tunga, que ele fez dentro do túnel.

LF: Eu vi na Candido Mendes. Fiquei completamente fascinada, mas era uma coisa totalmente longínqua da minha ideia de arte e do que eu fazia naquele momento.

AC: O filme é de 81. É um trabalho super atual também, não é datado.

LF: E o mais louco é que isso tudo, essa história de filme, veio por uma volta da filosofia, veio através do Nietzsche.

FP: Bonito isso, o eterno retorno.

AC: E eu fantasiando que era o Tunga.

LF: Não, o Tunga, só na hora que eu fiz, bem depois, as coisas se juntam. Aquela admiração intensa por aquele trabalho demorou muito para chegar a um filminho de um capim ao vento. Foi onde tudo começou. Que é o aqui não tem nada / aqui não falta nada.

MM: Esse título é maravilhoso.

FP: De onde vêm os títulos, Livia? Os títulos são muito importantes e esse lugar da palavra em alguns trabalhos.

LF: Sim. "aqui não tem nada", "aqui não falta nada" são frases que rondavam a minha cabeça. Tive o Emanuel em 1994, fiz o mestrado entre 96 e 98, em 97 nasceu o Pedro, eu estava morando na zona oeste, não estava trabalhando com arte, estava cuidando de crianças e escrevendo. E aí foi incrível porque um dia veio a Maria de Lourdes, da Galeria da Candido Mendes. Eu estava completamente despreparada e ela me convidou para fazer uma exposição. Comentei "mas eu vou precisar acabar a dissertação", e ela respondeu: "então a gente marca para 98".

O tempo passou e aí de repente eu terminei a dissertação e fomos fazer a exposição. O que vou fazer? Não tenho nada. Daí veio o nome. Era um sentimento meu, de um momento muito intenso que estava vivendo na minha vida.

MM: Essa é a essência dos trabalhos em artes, você não tem nada e não falta nada também.

LF: Eu não sabia nada de cinema, de filme. Eu perguntei para o Rai6: "Rai, tenho que fazer uma exposição, queria fazer uma imagem de capim ao vento, como é que faço isso? É $35 \mathrm{~mm}$ ?" Aí ele foi me ajudando, até que cheguei ao super- 8 , que me permitia ter imagem em movimento de baixo custo.

\footnotetext{
${ }^{6}$ Raimundo Bandeira de Mello, fotógrafo e cineasta.
}

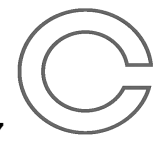


MM: Foi aí que você começou a acionar o super-8 do Tunga!

LF: É, foi isso, aí as coisas se reencontraram.

FP: E o Nietzsche?

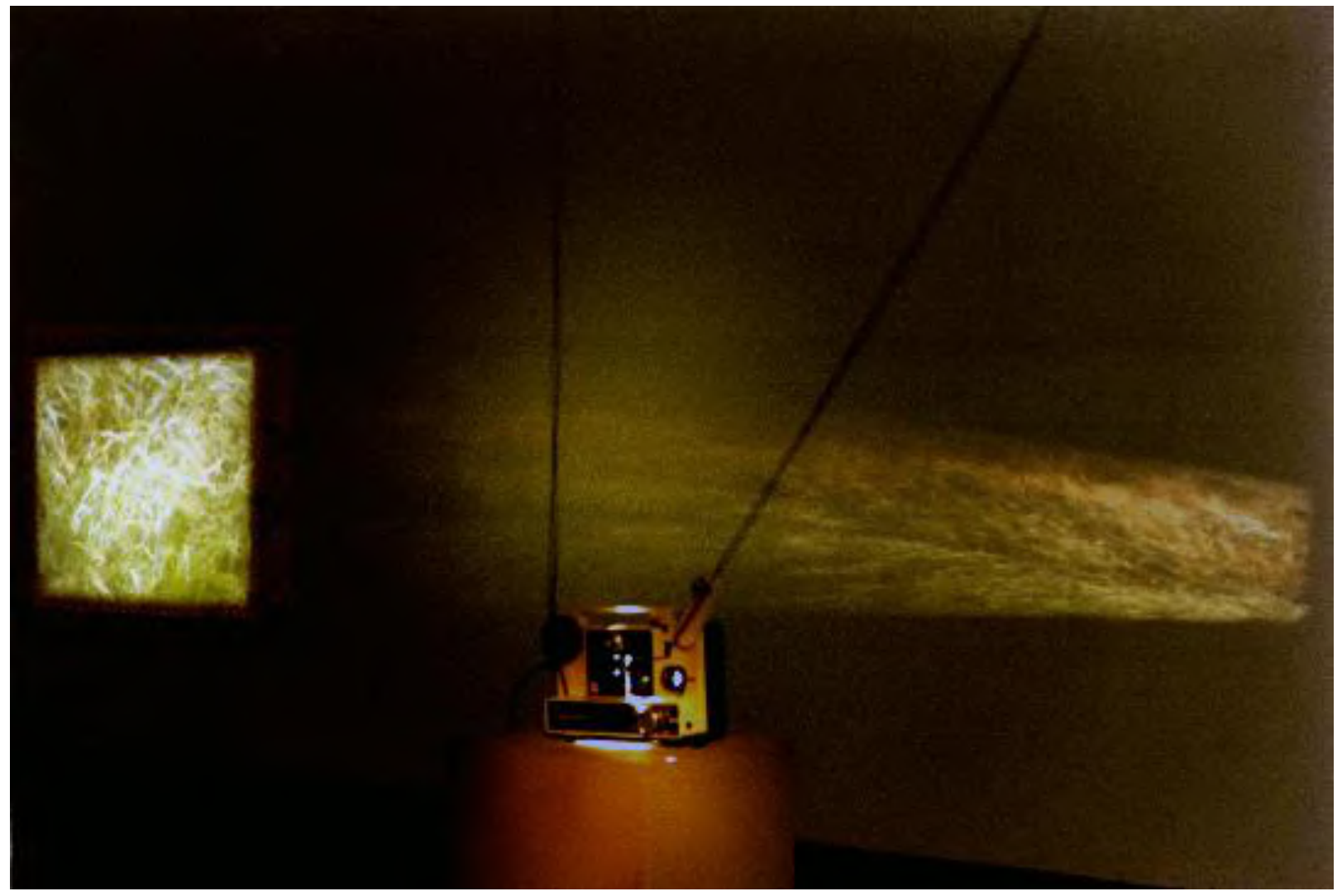

Instalação com filmes super-8, (aqui não tem nada / aqui não falta nada), 1998

4 projetores super-8, tela translúcida

Galeria Candido Mendes Ipanema

Foto: Wilton Montenegro

LF: O Nietzsche foi porque veio a pergunta do Eterno retorno ${ }^{7}$, em que ele fala assim: "-E essa aranha aí e esse raio de lua e tudo na mesma ordem e sucessão". É um pequeno trecho da formulação do Eterno Retorno. E aquilo para mim era incrível, a aranha e esse raio de lua.

\footnotetext{
7 “O mais pesado dos pesos. E se um dia, ou uma noite um demônio aparecesse furtivamente em sua mais desolada solidão e dissesse: Esta vida, como você a está vivendo e já viveu, você terá de viver mais uma vez e por incontáveis vezes; e nada haverá de novo nela, mas cada dor e cada prazer e cada suspiro e pensamento, e tudo o que é inefavelmente grande e pequeno em sua vida, terão de lhe suceder novamente, tudo na mesma sequência e ordem - e assim também esta aranha e esse luar entre as árvores, e também esse instante e eu mesmo. A perene ampulheta do existir será sempre virada novamente - e você com ela, partícula de poeira! (...)". NIETZSCHE, Friedrich. A gaia ciência. Tradução de Paulo César de Sousa. São Paulo: Companhia das letras, 2001, p. 230.
} 
FP: Bonita essa imagem da aranha porque a Lygia Pape, nesses trajetos que ela fazia pela cidade, na ordem desse tipo de gesto horizontal mencionado anteriormente, ela fala da teia e que ela era uma espécie de aranha, tecendo a teia pela cidade.

JPQ: É um nível de intensa associação com as coisas do mundo. Em Tunga e em Pape, aparece a mesma questão de como lidar com essa junção espaço-tempo entendendo-a como um contínuoinstável onde as coisas vão se alastrando, se conduzindo. Sua pontuação da realidade esparsa é uma forma de enfrentar o mesmo problema. Pensando de modo panorâmico sua obra, os próprios trabalhos são recuperados dentro de uma narrativa também contínua e instável. Seus trabalhos reaparecem de diferentes maneiras sem perderem seu referencial inicial. Você permite a eles voltar e, mais do que isso, permite a eles ir além de sua vocação original. Depois que tive a oportunidade de fazer uma exposição com você, estava olhando seu livro e vi o "estofado" em uma exposição dos anos noventa atuando de um modo completamente distinto. Essa continuidade da vida do trabalho indica uma lógica de produção mais expandida e menos categórica.

LF: Isso aconteceu mais recentemente. Começou a acontecer de uma forma mais consciente desde 2012. Desde que fiz a exposição na Galeria Progetti, quando comecei a reutilizar materiais que eu já tinha utilizado.

AC: Os tacos, o papel de presente...

LF: Sim, os tacos que tinham sido de outra exposição. Na verdade, isso começou em 2007, foi a primeira vez que eu recuperei uma produção muito antiga, que considero que tenha sido minha primeira produção, que foram os papéis colados [Telas].

\section{LF: Não!}

AC: Então... Vice-versa, é uma relação bilateral.

FP: E que talvez tenha a ver com aquela pergunta que a Maria fez no início, um pouco desse deslocamento, dessa prática dupla ou tripla, enfim, desses vários papéis, também como pesquisadora, como acadêmica, professora, como alguém que está engajada na formação de outros artistas, das demandas que a Universidade acaba colocando, como participação em bancas, produção de artigos etc.

LF: Acho que tem esse interesse pela periferia. Esse olhar a partir de uma margem é um olhar que me interessa.

JM: Essa era uma questão que eu queria saber mais, dessa relação com a Universidade, porque tudo bem, partiu de uma necessidade, mas também tem um prazer nisso, tem uma volta, isso te interessa? Ou você preferia estar... Um dia você me disse: “- estou pintando!", eu fiquei super curioso para saber se isso era uma prática para te aproximar mais do trabalho porque a pintura tem essa coisa, você não pinta uma pincelada e esquece, você fica ali, é uma coisa que está sempre te

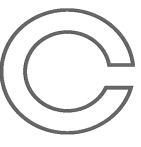




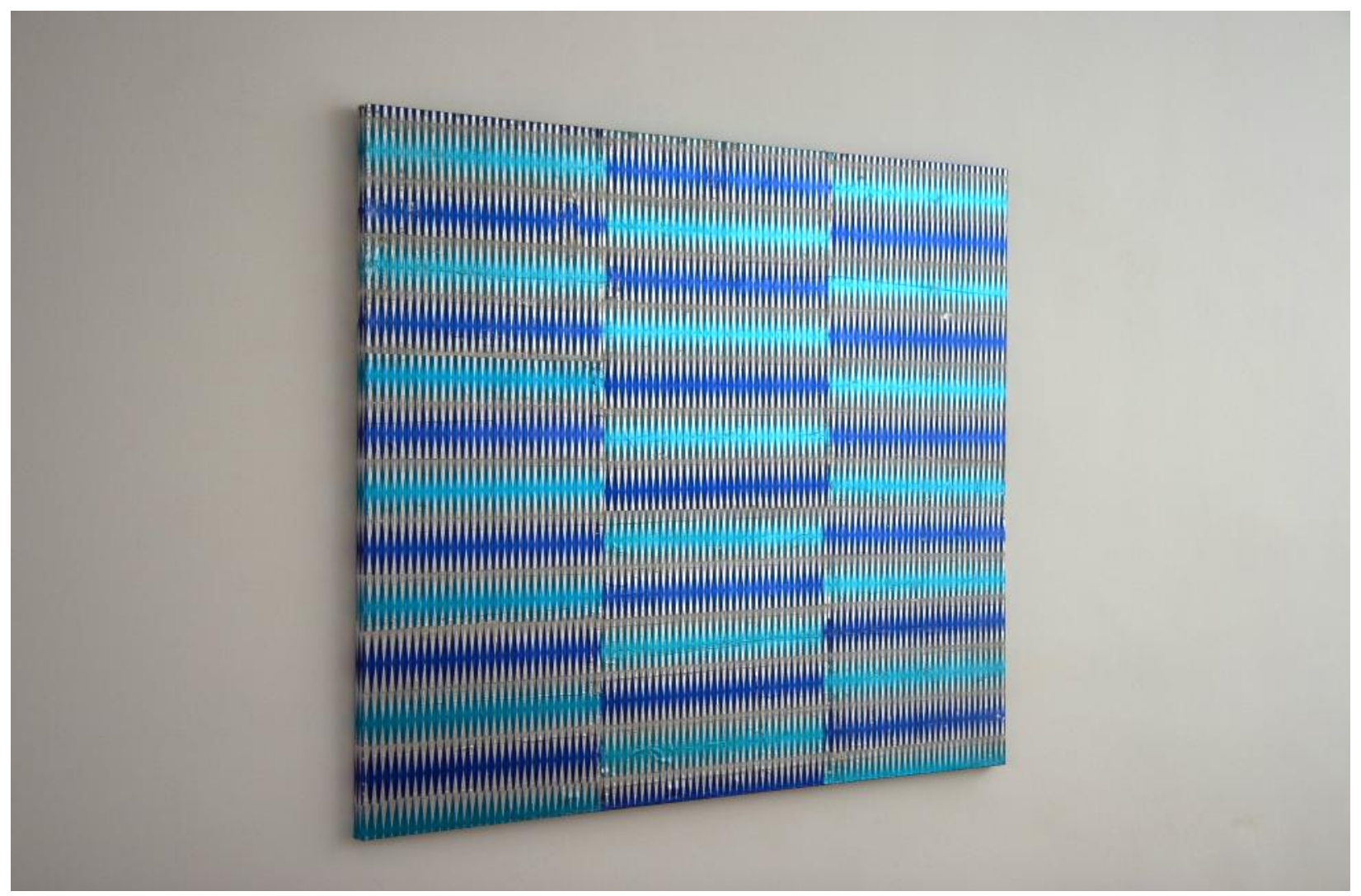

Azul-azul (telão), 1980-2007

Papel colado sobre tela, $135 \times 160 \times 2,5 \mathrm{~cm}$

Galeria Progetti, Rio de Janeiro

Foto: Wilton Montenegro

puxando e parece, eu não sei, não sou pintor, mas eu bordo, então... acho que é um pouco isso. Queria saber dessa relação, se tem interesse em mercado, ou não.

LF: Claro que tem um interesse, mas ao mesmo tempo tem dificuldades, enfim. No momento em que o mercado de arte se configurou no Brasil de alguma maneira, ali nos anos oitenta, eu estava na Alemanha.

JM: Não se configurou nos anos oitenta. Nos anos oitenta tinha duas galerias no Rio de Janeiro.

LF: Mas teve um certo boom das artes plásticas, da pintura. Parece que eu estou sempre meio deslocada. Claro, devo admitir que foi uma opção.

JM: Eu só estou especulando. Essa relação com o mercado é um desejo que precisa estar grande em você, você faz esses movimentos. Claro que tem casos, que a gente sabe, que o sujeito estava lá trabalhando, bateram na porta e aconteceu tudo. Mas, de um modo geral, eu acho que a gente

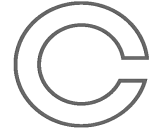




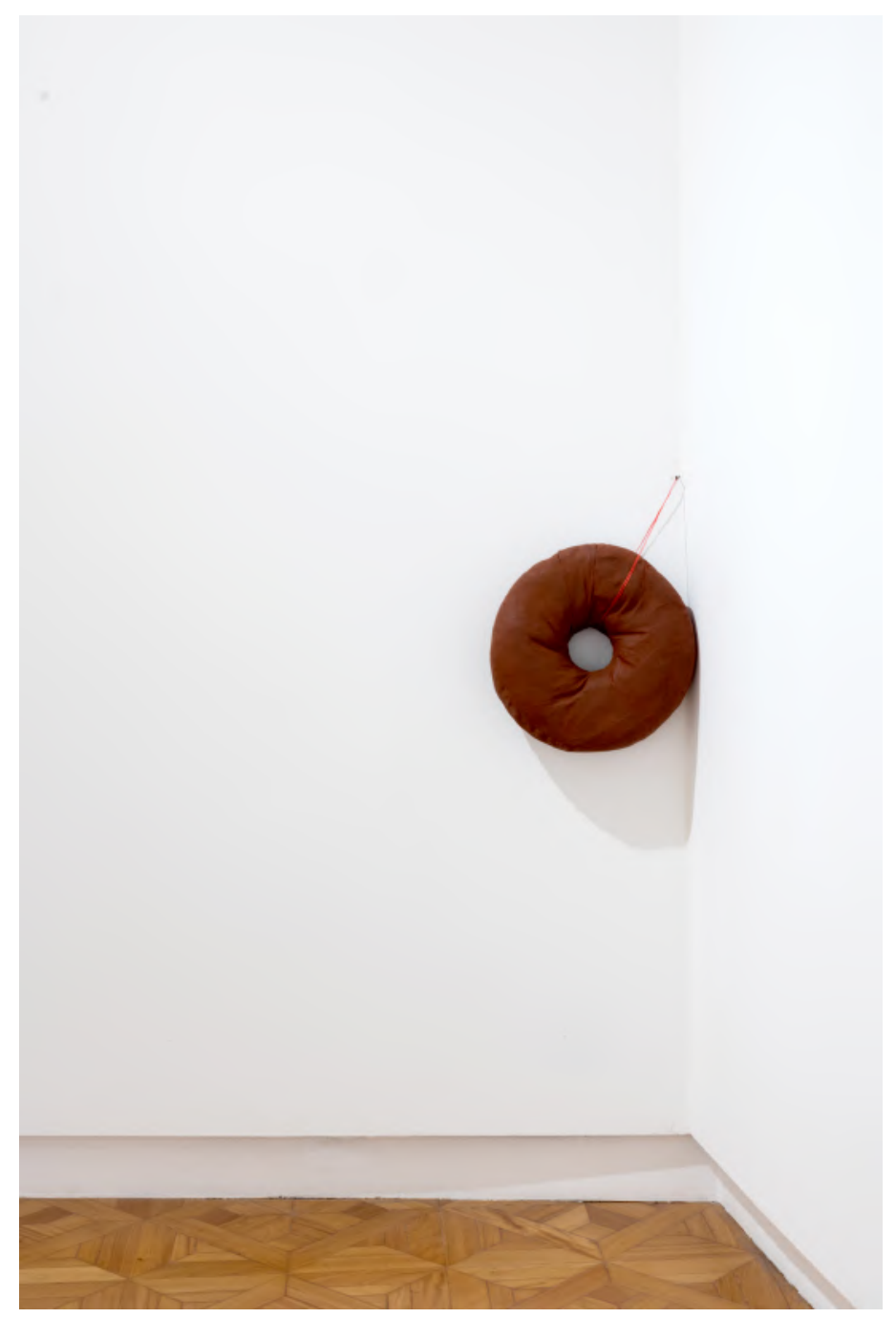

Sem título, 1990

Óleo sobre tela costurada e estofada,

$\varnothing 40 \times 10 \mathrm{~cm}$

ilha 03: Livia Flores, Projeto FOZ/Z42, Rio de Janeiro

Foto: Pat Kilgore

também precisa estar muito predisposto. Eu fico sempre pensando nisso, porque é tão bom ver o seu trabalho, mas você vê que é um trabalho que não está circulando. Hoje em dia o mercado faz essa circulação das obras, então quero levantar essa questão também, o quanto a Universidade também tira toda essa energia de ficar mais com o trabalho para o trabalho andar mais. Porque eu também fiz uma opção recente, pelo andar da carruagem, de abrir mão de outros projetos e concentrar no trabalho. Então é isso, me interessa muito esse assunto porque eu também estou passando por isso. Sei lá, queria saber de você.

LF: Eu acho que em algum momento a universidade se configurou como uma saída para a organização da vida, com meus filhos. Eu acabei investindo mais nisso mesmo porque também gosto de ler, de estudar, pesquisar. Tem esse interesse paralelo, digamos, eu acabei descobrindo

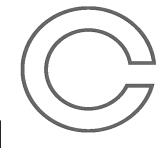


no mestrado e depois no doutorado que eu gosto dessa coisa. Depois que você faz o doutorado, para mim é claro você se encaminhar para uma carreira acadêmica. Mesmo que eu não tivesse consciência disso no começo, tinha interesse na bolsa. Mas em algum momento isso termina, e aí a condução natural da coisa é você ir para universidade mesmo.

JM: Mas você acha que é uma coisa que também traz coisas legais para o teu trabalho? Essa relação com a universidade.

LF: Sem dúvida. Eu acho que é a constituição de outra via possível para o trabalho.

JM: Te pergunto porque acho que você ter esse contato com a universidade traz uma dinâmica do pensamento, da relação com a vida, que é muito legal, porque a prática de ateliê é meio solitária mesmo, então....

LF: Faz parte desse meu interesse pela "cidade de tudo". Universidade para mim é cidade, é esse entendimento, essa busca por múltiplas vozes, por essas múltiplas possibilidades de criação.

JPQ: Tenho a sensação que essas motivações estão inscritas no trabalho. São termos que poderíamos problematizar: a margem, a lateralidade. Há muita coisa acontecendo em termos de experiência artística nestes lugares, inclusive muito para além dos movimentos mais centrípetos que o circuito mercadológico propõe. O interesse, a filosofia do trabalho da Livia está voltado para esses lugares outros.

LF: Me interessou muito criar uma independência do mercado, e pessoal também.

JPQ: Por sua relação com a cidade, conhecendo o projeto Desilha ${ }^{8}$ por exemplo, esses lugares outros têm o objetivo de lançar o olhar para fora dos tópicos da arte formal.

MM: Acho que ela fala margem, não como exclusão. A margem como local de escolha.

LF: Como escolher a perspectiva.

JPQ: É que a margem dá uma ideia de estar na borda, quase fora.

LF: A margem é sempre muito larga.

JPQ: Nesse sentido que acho legal pensar, que margem é essa?

\footnotetext{
${ }^{8}$ Desilha é um projeto de pesquisa em arte e cidade coordenado por Livia Flores, Ronald Duarte e Michelle Sommer. Desenvolvido no Programa de Pós-Graduação em Artes Visuais (UFRJ), inclui a realização de cursos, seminários e publicações transitando entre diferentes espaços da cidade e processos artísticos.
}

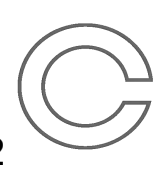




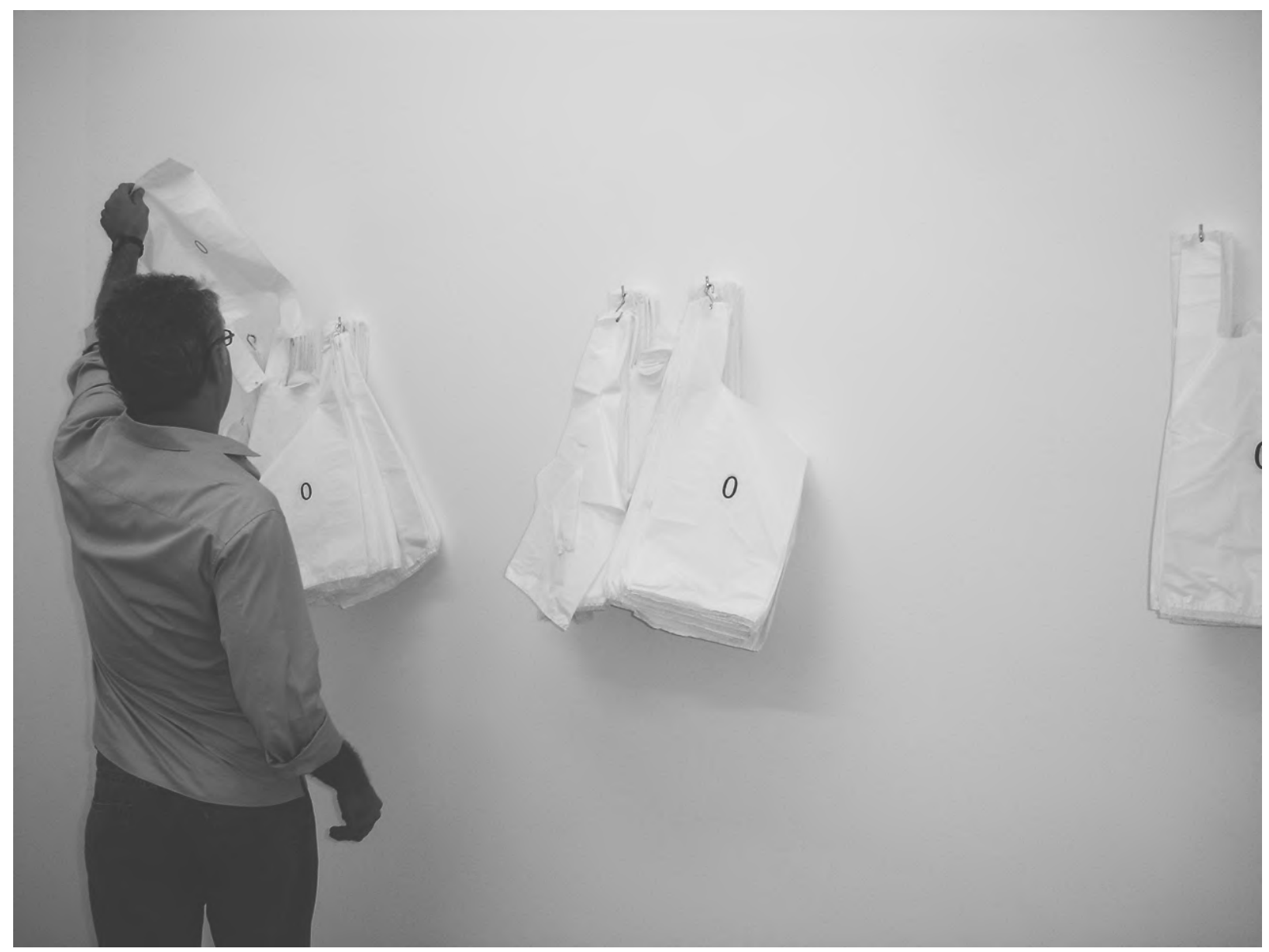

Saco zero, 2005

Impressão serigráfica sobre saco plástico

Anexo Laura Marsiaj, Rio de Janeiro

Foto: Raimundo Bandeira de Mello

MM: Quase fora sim, mas do quê? Pode ser um dentro também. Quando você escolhe a margem, ela é um centro de visada. Eu entendo essa coisa do movimento da margem para margem, ele me interessa também. Essa coisa centrípeta, da margem para o centro, é um moedor. Você vai entrar em uma máquina que é poderosa por ser centrípeta. Da margem para margem esse movimento é mais extenso, tem mais espaço.

FP: Que eu acho que tem a ver com alguns trabalhos seus que têm uma ironia fina. Tipo Saco zero, Aqui o sistema é bruto, o próprio Cadeia alimentar, que eu acho que tem a ver com essa tentativa, de alguma maneira, de decodificar esses funcionamentos, essas forças, e tentar lidar com elas de uma forma mais bem humorada, com mais leveza, menos como um imperativo, e mais como um jogo com essas ordens.

MM: A margem permite uma distância. 
LF: É isso que interessa, é a possibilidade de ter um ponto de vista, que é ter uma distância em relação a outro.

AC: Essa coisa do ponto de vista do trabalho, do seu ponto de vista, do seu trabalho que é muito plongée, lembrei do Feliz ano novo, que tem esse ponto de vista muito peculiar, da paisagem, e tem o ponto de vista do trabalho, que é de uma parte da cidade que ninguém sobe para olhar. Lembra?

$\mathrm{Na}$ época eu conversei com você sobre isso. E eu me lembrei de uma conversa recente, muito recente, sobre fantasmas. Você falava de uma experiência de estar sendo observada. Você não lembra? Veja se consegue articular do ponto de vista do seu trabalho...

MM: Na verdade, o evento te olha você vai lá e captura, para devolver o olhar à coisa que te olhou.

JM: Acho que tem super a ver.

AC: Nós estávamos falando de ver fantasmas. Você falou que se sentia observada e inversamente...

LF: Não vejo fantasmas, mas às vezes me sinto observada, sei lá....

AC: O invisível te olha e você se vê nesse invisível. Por isso que estou falando desse fantasma.

JPQ: Que me parece dar uma outra compreensão do mundo, que é dar mais um ponto de vista para as coisas. Margem não como lugar, mas como perspectiva para as coisas.

JM: Me lembrei de outra coisa, que eu vejo no trabalho. Que é essa coisa do uso dos espelhos, uso do carbono, a coisa do negativo, da imagem que está repetindo, o uso da câmera escura, que a imagem está invertida. Sabe, esse espelhamento das coisas, eu também queria que você falasse mais.

LF: Eu acho que tem esse interesse pelo negativo, acho que isso é uma coisa bem clara que vem de uma primeira experiência em arte, com xilogravura. Você cava na madeira e aquilo vira um branco, depois essa experiência vai se dar em três dimensões, com o trabalho em gesso. Fiz muitos trabalhos em gesso, tenho fascínio pelo avesso, pelo negativo, pelo latente. E aí entra também a fotografia, o filme.

JPQ: Essa ideia da imagem pelo espelho me lembrou uma anotação que fiz aqui: A imagem é uma intenção ou uma negação, intenção ou absorção, produção ou obtenção daquilo que está no mundo?

LF: Na verdade não dá para escolher um ou outro, são sempre os dois, são contínuos. É esse trânsito que me interessa.

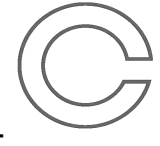




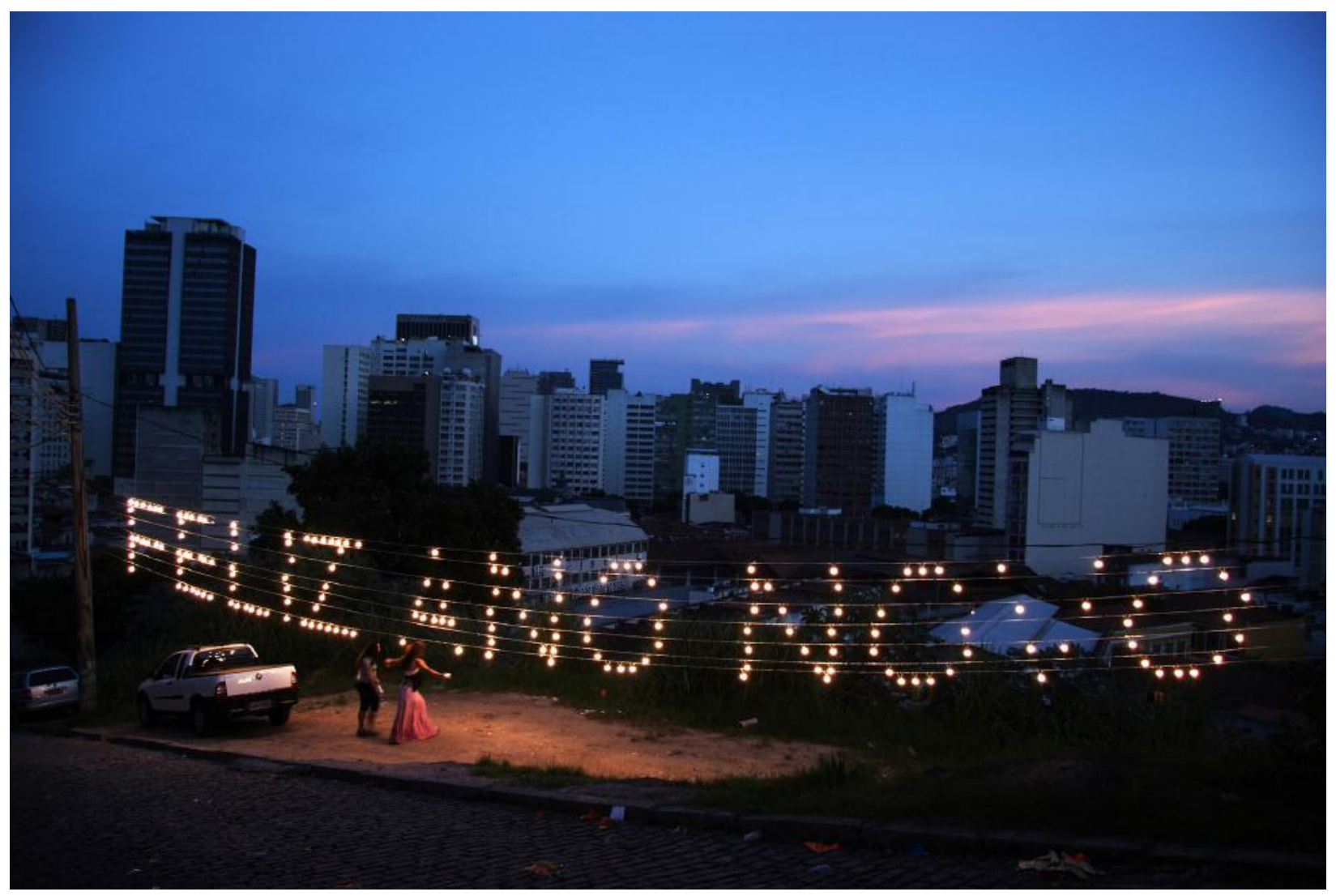

12.4.2008 / Feliz ano novo, 2008

Instalação temporária.

Fios elétricos, lâmpadas Dimensões aproximadas: $26 \times 2 \mathrm{~m}$

Intervenções artísticas no Morro da Conceição, IPHAN, Rio de Janeiro.

Foto: Wilton Montenegro

AC: É a afirmação dessa outra coisa?

LF: É a possibilidade de poder transitar entre uma coisa e outra.

JPQ: E esse lugar do que é observado ainda aparece também no Cadeia alimentar, foi um trabalho que a Fernanda comentou, com aquela vigília e também você que observa os tigres, cães. Tudo está sendo observado na cadeia alimentar e o público entra como mais um observador, como comentário ativo sobre a cadeia alimentar. É como se o título desse ao observador o topo da cadeia alimentar. Quem é que está se alimentando de quem?

LF: Quem come quem, quem é comido por quem? 


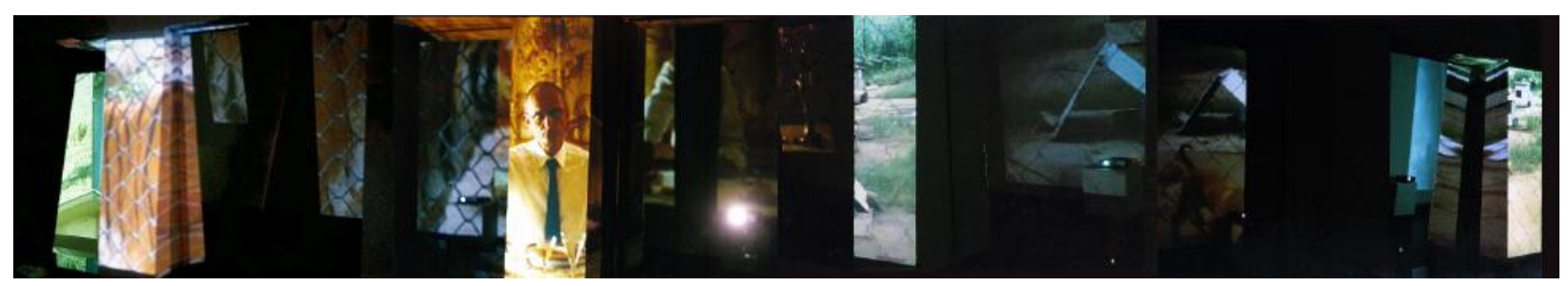

Cadeia Alimentar, 2004

Videoinstalação com os filmes homem, tigres, cães, guarita transcritos para vídeo, 5 projetores DVD, 11 espelhos Centre d'art Santa Mònica, Barcelona

Fotos: Livia Flores

FP: Livia, e na entrevista que foi publicada no livro, você faz uma relação dos filmes com desenhos, você lembra? Eu separei a frase em que você falou alguma coisa como: "quando fiz os primeiros filmes em 98 eu falava da relação entre cinema e desenho: o filme como aquilo que permitiria ver certos desenhos acontecendo, só que os desenhos não acontecem mais no papel, com a minha mão, mas acontecem ali com o que eu escolho enquadrar". E aí queria pedir para você comentar um pouco o Caderno Juquinha, e outras séries de desenhos. De que maneira o desenho é um procedimento recorrente ou que retorna, está sempre presente em sua produção.

LF: Meu ponto de partida foi o desenho, comecei desenhando durante bastante tempo. Hoje em dia eu quase não desenho, não é uma prática cotidiana, é bem esporádica. Mas naquele que foi o primeiro momento de abordar o filme, eu fiz essa relação, eu estava interessada em pequenos movimentos do mundo. Movimentos previsíveis, porém, sujeitos a falhas, que é o tal do capim ao vento, que quando fui filmar não tinha vento, a montanha russa que quando fui filmar não estava funcionando. Enfim, movimentos completamente previsíveis e cotidianos. Quando você consegue reunir as condições, se não tem o vento, como é que você vai produzir o vento? Não produz vento. Acho que ali, naquela primeira exposição de filmes de fato eram desenhos, movimentos do capim, movimento da montanha russa, substituído por outro brinquedo de parque de diversões, com pêndulo e o carro na curva que você completa o círculo mentalmente, o carro vem e passa, é isso que você vê, mas de alguma maneira quando ele retorna, você completa o círculo. Acho que Nietzsche tem tudo a ver com cinema, porque acessa essa capacidade de retorno do cinema, essa condição de um passado que retorna. De um momento fixado, extraído da vida... a aranha aí, a aranha, a lua e a janela...

AC: No livro, você fala que o cinema sem filme tem muito a ver com projeção. Você lembra disso? Era uma projeção de forma mais ampla. Talvez a questão do espectador....

LF: A possibilidade de você deslocar o filme, porque é um pouco isso. Se você mostra um carro em uma curva e o espectador projeta o círculo, de alguma maneira você está trabalhando com a projeção, que não é apenas a projeção física. E aí quando eu fiz as exposições em que saiu o filme mas permaneceu de alguma maneira a ideia de cinema, de projeção, que foram as Puzzlepólis, então aí já estou trabalhando com a possibilidade de uma projeção que não é mais produzida por um mecanismo e sim pelo imaginário do espectador.

MM: Engraçado porque o Robert Smithson diz que toda vez que ele entra em uma sala de cinema, quando o filme começa, imediatamente ele vai elsewhere, que é essa coisa desse espaço de

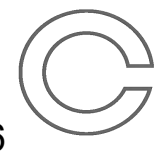


projeção. O que está na tela é uma coisa que te joga para outro lugar. É engraçado você ter citado essa exposição, a Puzzlepólis, eu estava vendo as datas, eu acho que ela é um pouco antes daquela outra exposição, que tem só o piso de tacos.

LF: Essa é a primeira Puzzlepólis, Sergio Porto, 2002.

MM: Logo depois tem Cadeia alimentar ou é um pouco antes?

LF: São juntas.

MM: Eu achei engraçado elas estarem juntas, quando você retorna a usar os tacos, lá na Progetti, tem uma frase maravilhosa sobre a coisa desértica da solidão ${ }^{9}$. Eu acho que está nesse movimento da autofagia, essa exposição do Puzzlepólis, é como autofagia expandida para incluir o outro, é o mesmo movimento.

LF: A frase é do Eurípides, das Bacantes [tradução de Trajano Vieira]. Não consigo entender muito bem essa autofagia.

MM: É a coisa que o João apontou, de os trabalhos retornarem, de você tratar os trabalhos quase como objetos migratórios. Dessa coisa de você se alimentar dos seus próprios processos, se alimentar da coisa já produzida, já concluída e que retornam num movimento elíptico. E o Puzzlepólis, eu li em algum lugar que houve uma certa incompreensão na época da exposição, sobre a relação de autoria, mas assim, para mim pareceu tão claro que era esse movimento da autofagia é uma coisa de você expandir o seu procedimento para incluir, acolher o outro. Talvez ocorrendo aí, aquele mesmo momento que a gente estava comentando há pouco, que a coisa te olha de volta e você se reconhece nessa coisa que te olha.

LF: Na verdade são dois trabalhos chamados Puzzlepólis, que são os trabalhos que eu fiz com Clóvis, com peças do Clóvis, que para mim é esse espelhamento pelo avesso total, enfim, o encontro com esse artista que é uma espécie de avesso. Homem negro, morador de rua, que eu encontro em uma instituição para moradores de rua, e vou acompanhando.

MM: Ele é a margem radical.

LF: é... Mas pra ele essas questões nem se colocam... ou pelo menos não se expressam da forma como nós colocamos.

JPQ: Tem uma questão aí que acho muito particular, que é quando você inclui o trabalho de outro artista no seu trabalho. Parece que a questão da autoria talvez nem esteja em jogo. E essa questão que a Maria colocou, do autofágico, talvez indique uma ideia de consumo, ou autoconsumo, que não sei se vejo exatamente dessa maneira no trabalho.

9 “Ó megaluz do bacanal de Evoé, me alegro: a solidão me era desértica”.

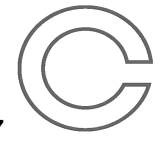




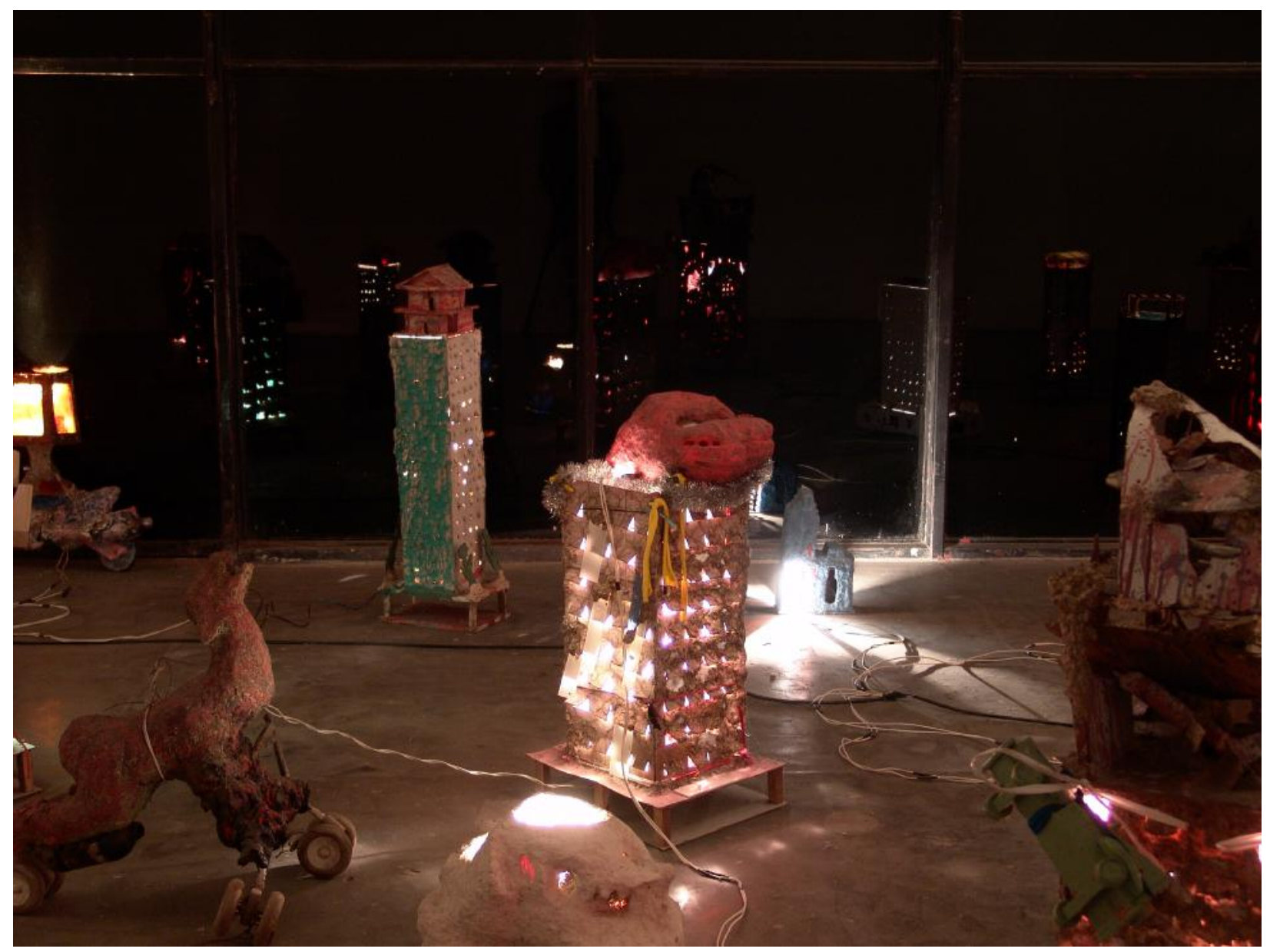

Puzzlepólis II, 2004

58 peças de Clóvis A. dos Santos, fios elétricos, lâmpadas, vinil preto adesivado na face exterior do pano de vidro $26^{a}$ Bienal de Arte de São Paulo

Foto: Wilton Montenegro

MM: De uma autoalimentação. Uma retroalimentação.

JPQ: Fico com a sensação de ser mais uma reincidência ou uma reaparição, talvez tenha mais a ver com a ideia dos fantasmas, do que com digestão... Por exemplo, a relação com o Clóvis, que é um caso super particular, algo como uma poética compartilhada, está ligada de alguma forma à ideia de experiência, mas, como você mesma falou, da experiência como um encontro, e não como algo preparado, anunciado, de onde você imagina receber algo, mas sim algo mais aberto: experiência como relação. E aí tem a ver também com a relação com o mundo e a cidade, então quase não há mais diferenciação entre sujeito, objeto e experiência. O Clóvis está atuando como artista, como no vídeo Carro coração ${ }^{10}$, executando um trabalho, pintando um objeto, e, ainda assim, é um trabalho no qual a autoria é sua. O que você está filmando é o registro mas é também a experiência em si. Você está contando a experiência e o trabalho é precisamente essa passagem

\footnotetext{
${ }^{10}$ Disponível em: https://vimeo.com/260878845
} 
contínua do fazer do Clóvis para o seu vídeo. O trabalho tem esse estatuto muito fluido, como um território de passagem. Pode parecer haver uma reverência ao Clóvis, mas não, é o contrário: é uma confiança e mutualidade total entre esses dois autores ali presentes. É muito particular essa relação com o Clóvis, como ele entra no trabalho. É ao mesmo tempo franco e cuidadoso.

JM: Você que propôs a ele fazer o carro?

LF: Na verdade foi assim: ele tem vários carros, desde 2002, que foi o momento em que eu o conheci, ele já tinha carros, prédios e casas. Naquele momento, o que me interessou no primeiro trabalho foram as questões da casa, no segundo, a questão da cidade, mas já havia os carros e aí teve esse evento, que é para mim muito marcante, que foi quando a Fazenda Modelo estava sendo desativada, e ele permaneceu lá até o fim ocupando o que era o antigo ateliê de artes e artesanato. Então, ele ocupou completamente o espaço com todos aqueles objetos, muito mais, e à medida que a pressão foi aumentando para que ele saísse e para que eu também retirasse as obras que iam para a Bienal, ele começou a construir lá dentro um carro de cimento em tamanho natural. Aquele carro é um monumento. É um auto-imóvel. Aquilo ficou na minha cabeça como desejo de revelar esse monumento. A ocasião que se apresentou possível foi quando a Tania Rivera me convidou para participar de Lugares do Delírio, mas que no desenvolvimento do trabalho tomou outros caminhos. Virou a tentativa de o carro ser móvel, mas ele resistia à mobilidade.

AC: Mas ele chega a se deslocar por ali?

LF: Não!

JPQ: É o mesmo carro que ele tinha feito antes?

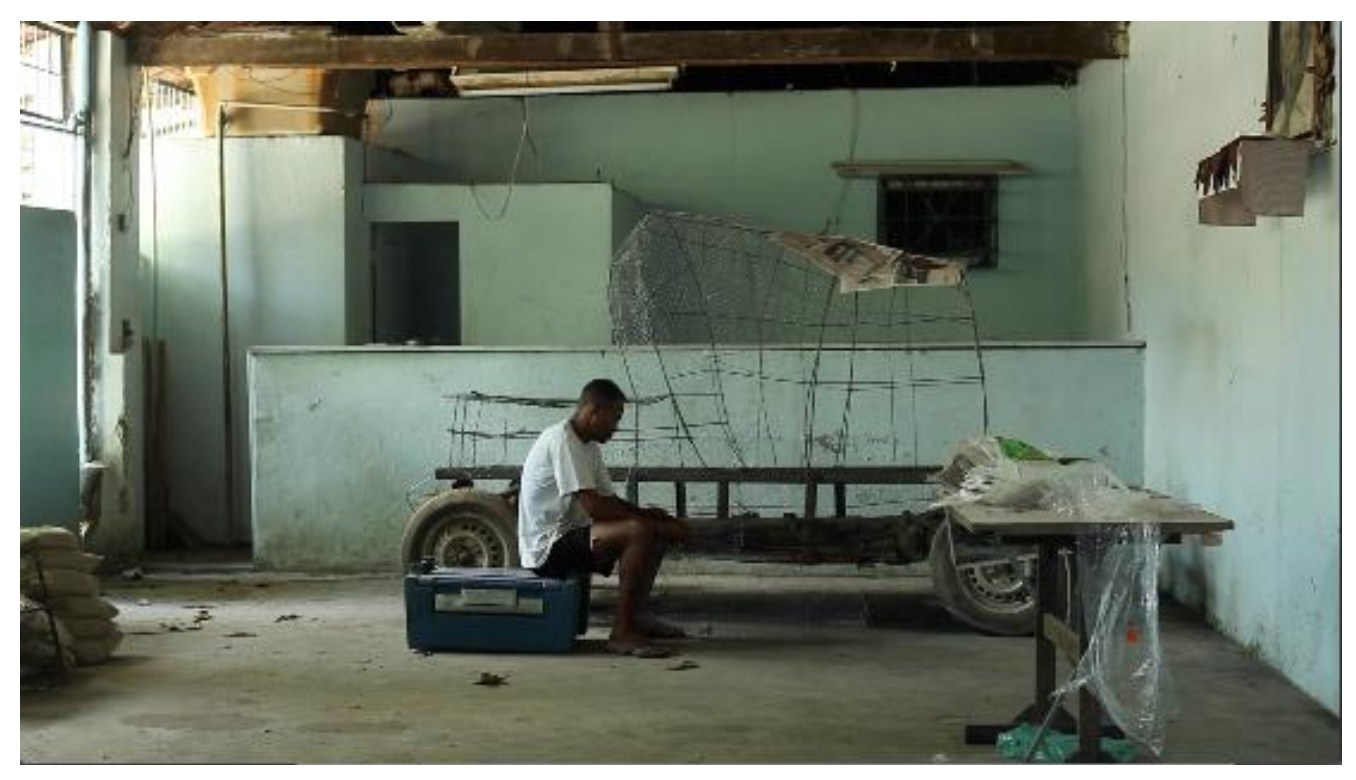

Carro-coração, 2017

Frame de vídeo de Livia Flores e João Wladimir Bernardes, 23’07

com Clóvis dos Santos e Bloco Carnavalesco Império Colonial 
LF: Aquele carro que eu via como um monumento ficou lá, mesmo com a Fazenda desativada. Fui lá de novo alguns anos depois, e o carro estava lá. Então, em 2016, eu voltei, será que o carro ainda está lá? Aí já não estava. Eu perguntei se ele teria interesse em fazer outro carro grande, foi isso.

MM: Ele foi para onde depois que a Fazenda foi desativada?

LF: Clóvis foi para um hotel no Centro, pago pela Prefeitura. Eu não quis comprar as peças, preferi dividir o dinheiro do pró-labore com ele, assim as peças continuariam sendo dele. Depois, quando elas voltaram para cá, eu também não queria ficar com elas. Naquele momento, eu conheci o pessoal do Museu Bispo do Rosário ${ }^{11}$, que estava com essa proposta de relação com a arte contemporânea. Eu mostrei o trabalho, eles se interessaram em ficar com as peças e acolheram também o Clóvis. Quando isso aconteceu eu estava fora do país, não foi formalizado um acordo e todo esse conjunto acabou se perdendo.

JM: Como assim se perdeu?

LF: Foi exatamente assim que o Ricardo Rezende me falou: "Se perderam”.

JM: Os prédios já vinham com lâmpadas dentro? No Sérgio Porto já tinha lâmpada dentro?

LF: No Sérgio Porto eram duas peças: uma casinha e um abajur.

MM: O que tinha escrito?

LF: Cadeia alimentar. Porque ele já escrevia coisas nas lanternas que aquecem com o calor da luz e giram. E aí eu pedi pra ele: "você faz para mim uma com essas palavras?" Aí ele fez um monte de copos: cadeia alimentar, cadeia alimentar...

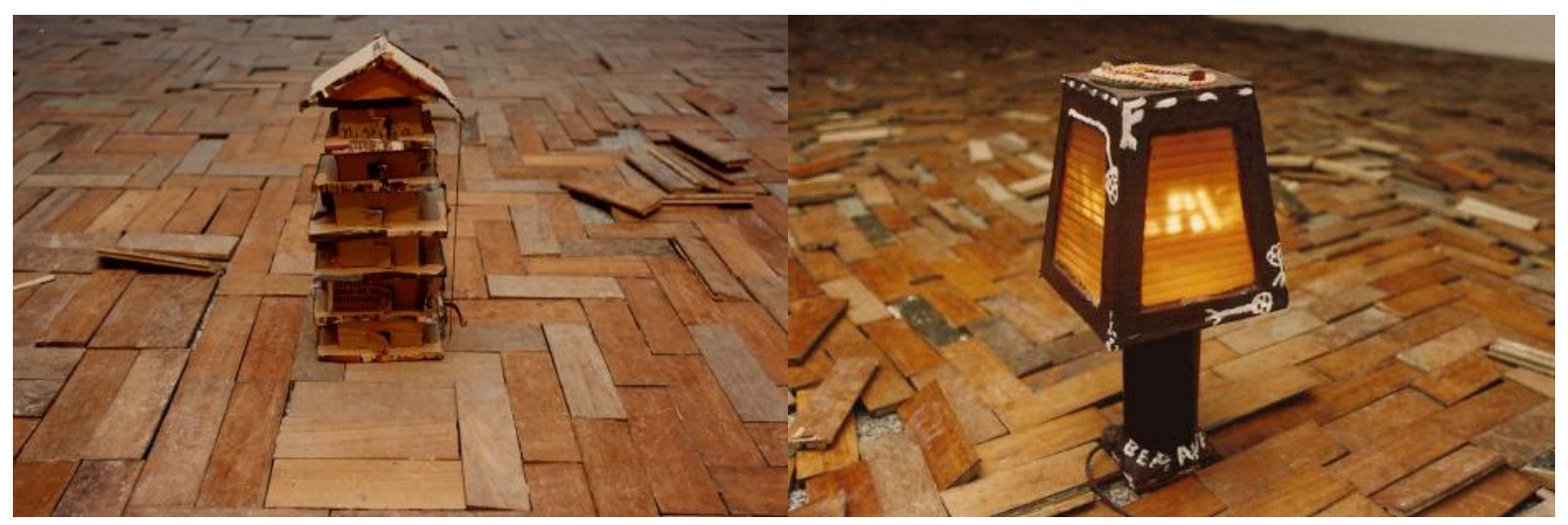

\section{Puzzlepólis, 2002}

Tacos de madeira, casa de papelão e abajur de autoria de Clóvis dos Santos

Espaço Cultural Sérgio Porto, Rio de Janeiro

Fotos: Paulo Jares

\footnotetext{
${ }^{11}$ Gestão de Ricardo Aquino e Wilson Lázaro.
} 
JM: Não tem uma foto da sala inteira aí? Era uma relação da sala e da sala com os objetos.

LF: Eram objetos pequenos em uma sala grande e escura, na foto fica difícil mostrar os objetos e a relação espacial deles com a sala.

AC: Voltando à conversa da projeção, você fala na entrevista da projeção também no sentido social, do deslocamento do Clóvis para Bienal. Isso que eu queria falar na hora, desse Cinema sem filme, entende?

LF: O cinema sem filme vem dessa experiência, é uma elaboração. Eu vinha de uma série de instalações com filmes, e aí eu passo a fazer instalações onde o filme desaparece, mas pra mim havia uma ideia de cinema que se mantinha. Como entender essas duas coisas que não seja pela materialidade?

AC: É porque o projetor não está onde é projetado, é dessa distância que estou falando.

LF: Então, essa primeira exposição foi em 2002 e a segunda em 2004, como um desdobramento da primeira. Todas as duas são Puzzlepólis. A segunda, que é a Puzzlepólis 2, era um desdobramento da primeira. Porque quando o Alfons Hug me convidou para a Bienal de São Paulo, ele queria esse trabalho que eu havia mostrado no Sergio Porto e também no Novo Museu de Curitiba. Eu falei: tudo bem, mas tem um mundo de casas e prédios que eu quero trazer para uma versão ampliada do trabalho. Quando o levei à Fazenda Modelo, ele concordou.

JM: Tinha uma relação ali muito de você adentrar o trabalho. O som dos tacos, a precariedade dos objetos que era uma coisa muito forte. Na montagem da Bienal tinha os prédios, aquela cidade, uma coisa escura. Teve também o espelhamento, mas tinha aquele caminhozinho que você tinha que passar... Por ser bienal, tinha uma cordinha.

LF: Isso foi uma opção minha. Eu fiquei preocupada com o trânsito do público por entre as peças, porque eram muitas peças de materiais precários, com muitos fios elétricos entrelaçados porque elas eram iluminadas. Fiquei preocupada com acidentes e acabei optando por essa solução.

JPQ: Isso me faz pensar nas diferentes formas de estar com o trabalho. Tenho uma questão que é sobre o conceito, ou categoria da Arte, entendida como instalação. É uma ideia que está sempre considerando a presença desse espectador/público. E tem um limite também. Eu tive esse sentimento trabalhando com você em ilha 03. Havia uma unidade em uma sala, onde todos os objetos pareciam estar falando entre si mas, por outro lado, cada um preservava sua autonomia, então são trabalhos e não exatamente uma instalação. É interessante porque você dá uma chacoalhada nessa ideia. A minha pergunta seria se instalação é um conceito válido, se você trabalha com ele, mesmo porque você provoca com o "cinema sem filme" também esses conceitos. No seu livro, a Tânia Rivera e o Adolfo Montejo Navas também comentam essas situações.

LF: Lá na FOZ, a gente ficou com essa dúvida, se seria um único trabalho ou se manteria um pouco essa mobilidade do trabalho, de poder ficar no chão, ou de se elevar como muro, ou de subir um pouco só e se espalhar.

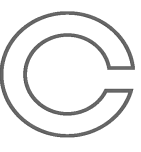




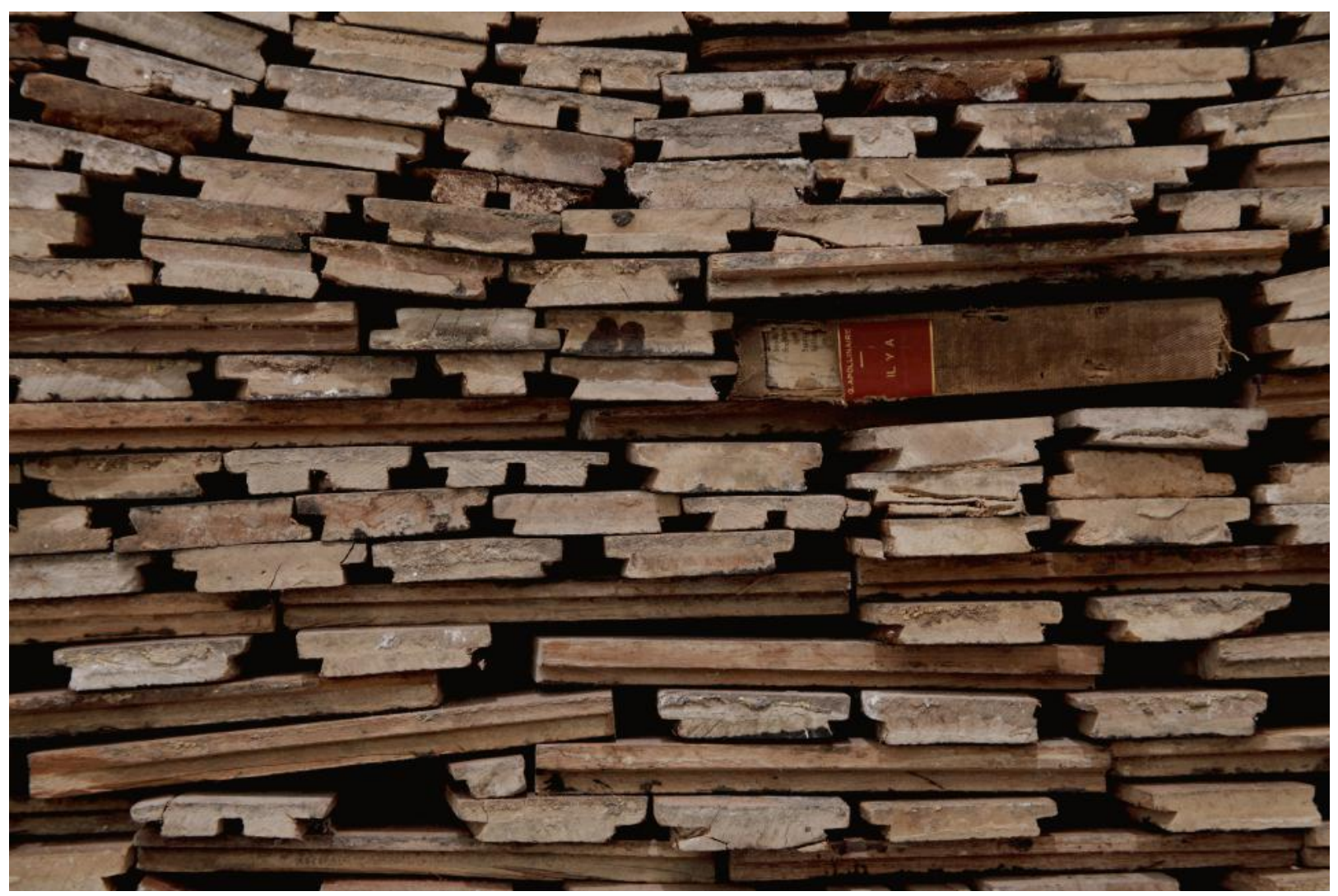

Sem título (Il y a), 2012

Tacos de madeira, 2 livros, folhas de papel impressas, $1,80 \times 6,00 \times 0,20 \mathrm{~m}$

Galeria Progetti, Rio de Janeiro, 2012

Foto: Wilton Montenegro

JPQ: Mas você prevê um pouco, como o João falou. Em Puzzlépolis, você entrava, pisava, ouvia o som dos tacos soltos. Você queria provocar a experiência do espectador.

LF: Na primeira versão era para entrar, para pisar mesmo. Na segunda também seria, mas por ser essa situação de Bienal, com grande afluxo de público, optei por limitar a circulação.

Não tinha jeito, ou você ficava de fora ou você entrava.

JM: Tinha uma instabilidade, uma precariedade nas peças.

AC: Falando de taco, também tem um trabalho que eu gosto muito que é o Il y a, lembra dessa conversa que a gente teve, em que eu falei de Il y a no sentido de ter e você falou no sentido de estar, né?

LF: De haver. Il y $a=$ Há. Na verdade, foi um livro que se intrometeu nos tacos.

AC: Do Apollinaire. Muito bom isso, um haver ali nas frestinhas. Entre os tacos que estão horizontais como se fossem tijolos. 
MM: Eu acho engraçado porque quando eu vi a foto do Puzzlepólis, o primeiro, Puzzlepólis1, vi junto com os outros trabalhos que são de projeção e assim a minha leitura mais imediata, é que são telinhas, as telas múltiplas que você tem na projeção, se multiplicaram ad infinutum em cada taco / telinha. Leitura delirante. Porque você passa de uma série de trabalhos que está lidando só com imagens projetadas, algumas impressas, para uma coisa da incorporação dos objetos. Mas, em algum lugar, uma coisa puxou a outra, tipo assim, a forma de pequenos retângulos como telas. Os pequenos tacos fazendo em algum ponto, a multiplicação das telas.

LF: Talvez essa ideia da projeção venha com o próprio material. São chãos de muitas casas.

MM: Portanto, carregados de projeções.

AC: De fantasmas

FP: Eu acho que tem a ver, como essa característica que a Analu falou de um plongée, mas que eu vejo mais como um aterramento. De fincar na terra. O rés do chão...

LF: Eu gosto muito de fazer objetos para o chão, ocupação do chão. Talvez esse tenha sido o mais chão.

MM: É margem mas não é sem chão?

LF: É instável, mas é chão.

FP: É interessante tentar retomar a discussão do desenho, talvez por outro lugar. Tem um texto muito bonito do Mário de Andrade sobre o desenho, em que ele fala dessa relação íntima com o desenho ${ }^{12}$. Ao mesmo tempo, tem um texto do Walter Benjamim que fala do grafismo do chão, esse lugar do desenho como o da horizontalidade, do descanso, da morte, em certa medida. E aí queria tentar retomar.

$\mathrm{AC}$ : Onde está isso?

FP: É um texto de juventude do Benjamin chamado "Sobre pintura ou Signo e mancha", foi traduzido pela Editora 34 no livro Escritos sobre mito e linguagem.

Porque é uma imagem muito bonita desse aterramento, desse chão, pensar nesse lugar do desenho também como o da horizontalidade, seja da prática, e também esse lugar da sutileza, de uma não monumentalidade. Se a pintura está para a hierarquia, para a história, para a parede, para essa verticalidade, o desenho estaria nesse lugar da mesa, de um fazer menos monumental, antifálico (risos). Não sei se você quer falar um pouco sobre o desenho, fazendo uma ponte com outros trabalhos seus, que estão nesse suporte mais do livro, do caderno também, esse lugar mais íntimo de você ter para si, de uma escala um para um. Sinta-se à vontade se quiser comentar seja os desenhos, seja os livros.

12 ANDRADE, Mário de. "Do desenho". In Aspectos das artes plásticas no Brasil. São Paulo: Martins Fontes, 1975. P. 69-77. 


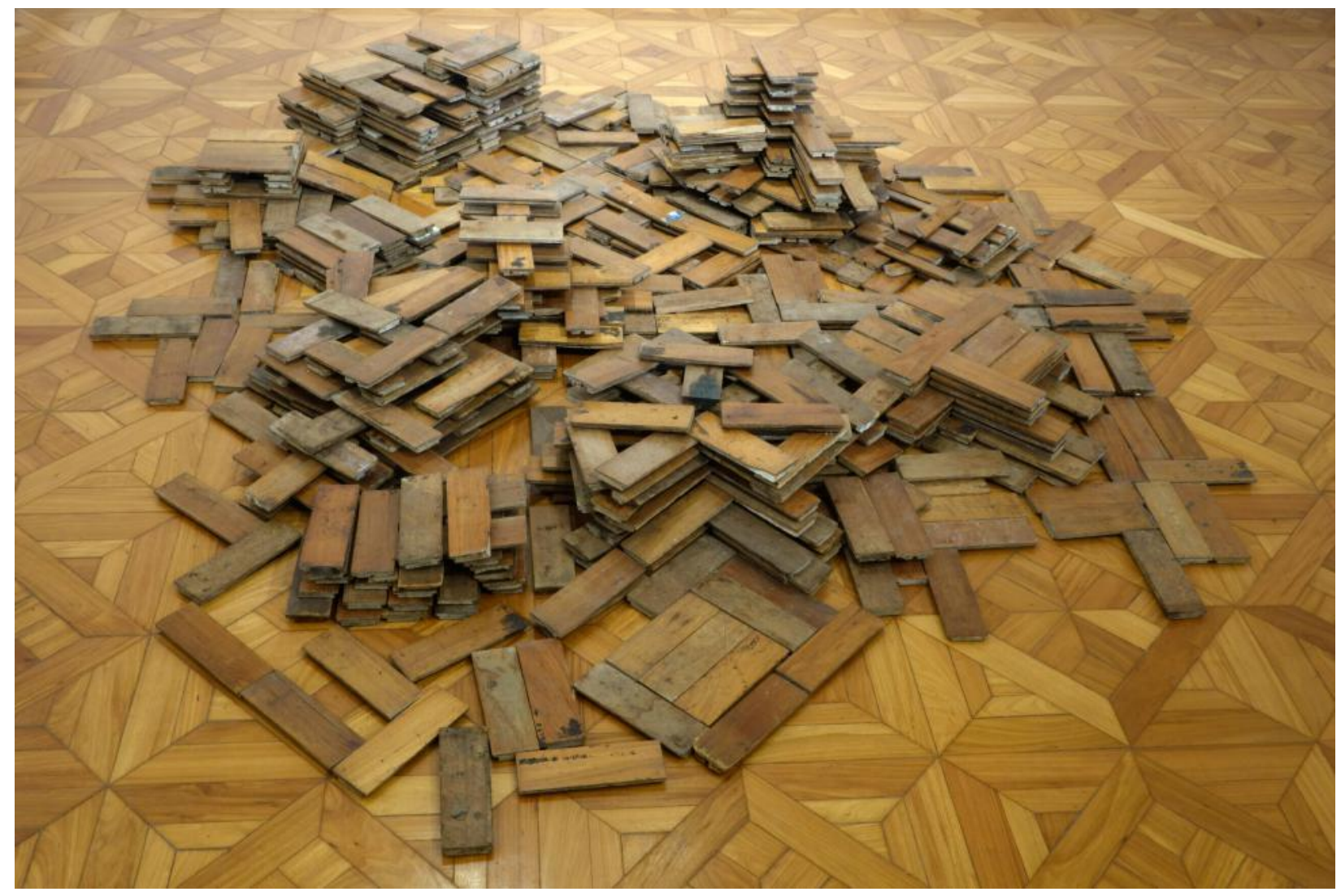

Puzzlepólis, 2018

Instalação com tacos de madeira

Dimensões variáveis

ilha 03: Livia Flores, Projeto FOZ/Z42, Rio de Janeiro

Foto: Wilton Montenegro

LF: Eu acho que nessa organização dos tacos, seja no chão, seja na parede como muro, ou nesse intermediário, como aconteceu lá na Foz, tem uma relação entre desenho e escultura muito forte. A mesma coisa com os Trabalhos de Greve. Na verdade, tem um esquema de desenho ali, mas que se manifesta no espaço. Então a instalação me interessa porque lida com espaço. Trabalhar no espaço é muito mais próximo da minha observação, que se dá no espaço, nos deslocamentos espaciais. É claro que os tacos são uma fonte de desenhos. Aqui eles aparecem já remexidos, mas houve um trabalho de encaixe, de desenho, de padrões que vão se modificando. Lá na Foz, eles se organizam a partir do desenho pré-existente do chão de tacos do assoalho da casa. Tem esse interesse também por certos padrões, que são desenhos, mas que podem ir pro volume, transitar em direção a uma ocupação do espaço.

FP: É bonita essa relação com o grafismo que você fez nos tacos, tem bastante a ver com essa discussão do Benjamim nesse texto. Os grafismos, as pastilhas do chão...

LF: Dos mosaicos, a ideia de partes contíguas se comunicando. 
JPQ: Tem algo que você falou, ou que alguém falou, não lembro bem, que diz que a gente só entende o espaço a partir do deslocamento, que o deslocamento constrói o espaço.

LF: Eu acho que o Puzzlepólis tem esse entendimento daquele espaço, daqueles $90,100 \mathrm{~m}^{2} \mathrm{da}$ galeria em relação à cidade. Ao mesmo tempo, ele é preenchido por muitas casas demolidas. É material de demolição. Não são tacos novos. É uma interrogação sobre aquele espaço, qual a sua destinação enquanto lugar de arte no contexto da cidade.

JPQ: Aí tem o Trabalho de greve, pelo qual a gente passou um pouco rápido, mas acho que poderíamos, até pelo momento político atual, retomar. O título é tão forte... e traz os cobertores dos moradores de rua. Você une os cobertores a um material improvável que é o gesso. Eu acho essa união de materiais uma questão escultórica muito forte. Parece que tem uma relação com o Beuys, com o feltro. Esses materiais têm certo lugar simbólico, social, e você os leva para uma experimentação estética, material, muito forte. Sou fã dos Trabalhos de greve. Se quiser falar um pouco de como eles vão aparecendo.

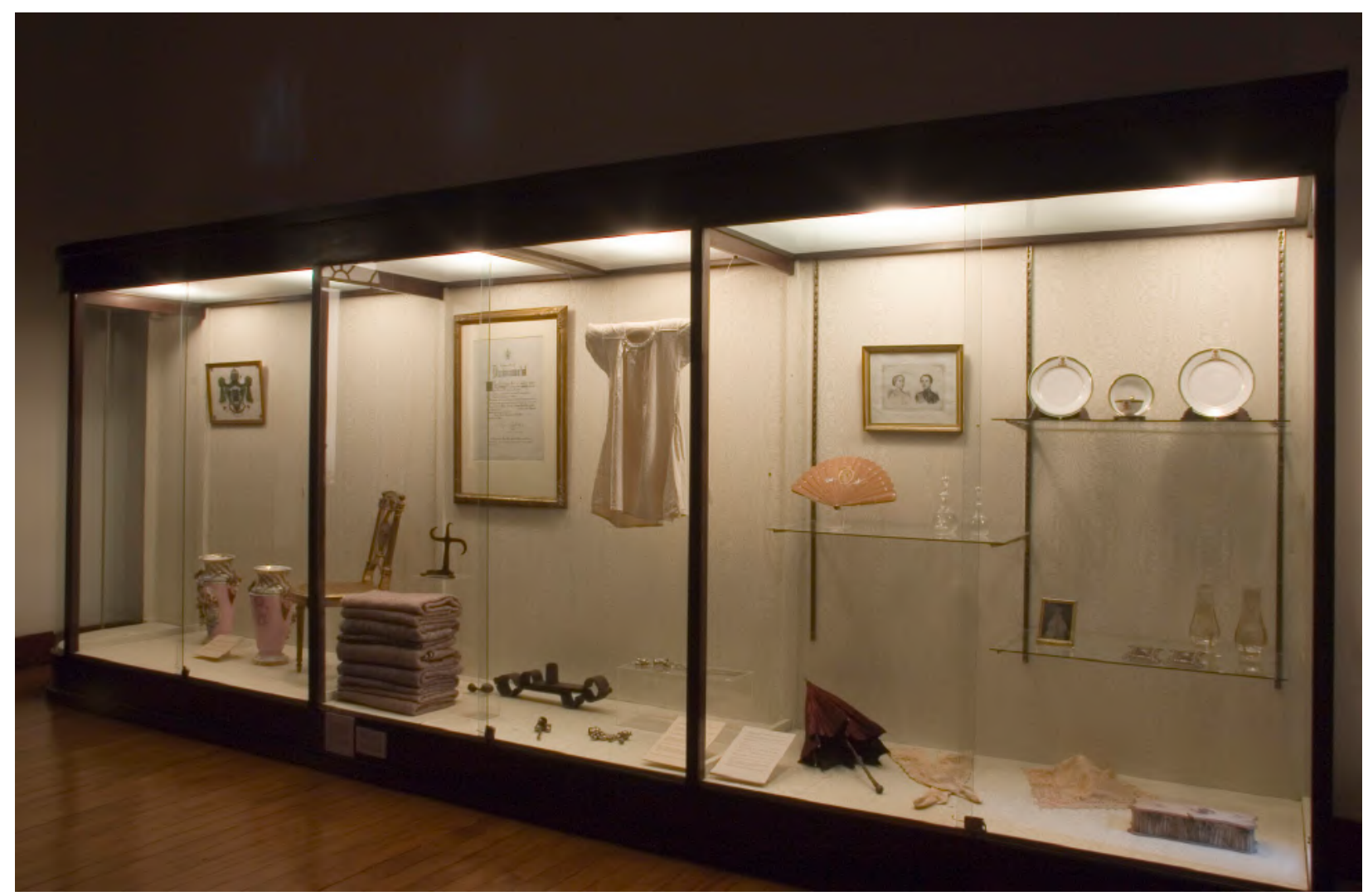

Pilha, 2007

Cobertores cinza empilhados em vitrine da Sala Princesa Isabel

$60 \times 40 \times 20 \mathrm{~cm}$

Museu como Lugar, Museu Imperial Petrópolis

Foto: Wilton Montenegro 
LF: Na verdade, os cobertores apareceram pela primeira vez em uma exposição feita no Museu Imperial em Petrópolis, que era uma proposta dos artistas intervirem naquele espaço museológico.

AC: Dobradinhas na vitrine?

LF: Eu intervim na vitrine da Sala Princesa Isabel, que tem uma vitrine que exibe a Lei Áurea. Embaixo tem alguns instrumentos de tortura dos escravizados, parte de uma vitrine maior que tem louça e outros objetos. E aí eu coloquei esses cobertores dobradinhos. O trabalho se chama Pilha, é uma aparição bem discreta. E a outra intervenção na mesma exposição em outra sala, o quarto dos Imperadores, ficava sobreposta à cama do casal, como uma espécie de estoque. O que essa cama de casal produziu? Qual foi a produção do Império? Tinha um acúmulo de cobertores. É esse material que volta para o ateliê e está disponível para novos trabalhos, novas transformações.

MM: É a passagem da pilha para o trabalho que remete ao Beuys, que foi uma experiência concreta para você.

LF: Tem Beuys e tem o Morris... já que estamos falando de cama de casal, é o casamento dos dois em solo brasileiro.

MM: Isso, o solo brasileiro. É todo peso que vem da maneira que você usou o material no outro trabalho. Essa coisa da precariedade que vivemos, porque aquele cobertor não é o feltro do Beuys. E a carga que vem dessa incompletude institucional sobre os destinos, ela filtra pessoas e trabalhos.

LF: Não é o feltro do Beuys, não é o feltro do Morris.

MM: Tem uma melancolia que filtra dentro desse gesto estético. Tem essa melancolia constante, que a gente não consegue se livrar, das possibilidades que não se completam.

LF: Essa construção que arruína, essa dinâmica da ruína está muito presente no trabalho nessa exposição mais recente. $\mathrm{O}$ tempo se traduz como fragilidade, vulnerabilidade.

MM: Que é o destino nacional, você passa da promessa para a ruína, sem nada no meio.

JPQ: Mas ainda assim, ele tem presença em relação aos outros trabalhos. Ele se anuncia mais no espaço.

JM: Sim, é verdade. 


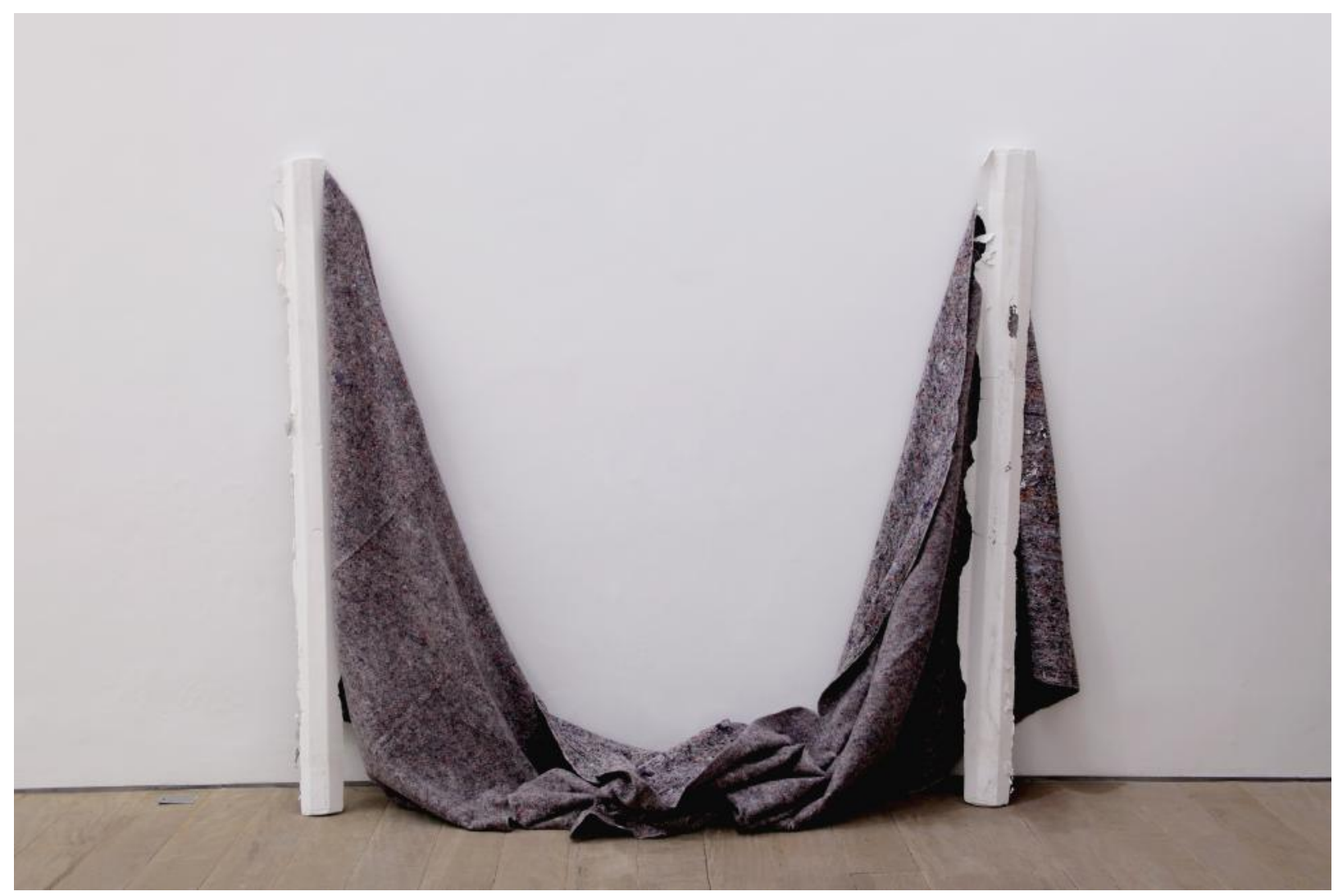

Trabalho de greve, 2012

Cobertores cinza, gesso, sisal, dimensões variáveis

Galeria Progetti, Rio de Janeiro

Foto: Wilton Montenegro

LF: Apesar de ser mole, ele tem uma robustez.

JPQ: E também vai deitado.

MM: Ele é monumental, mas é irônico da monumentalidade. Ele já se anuncia como ruína: “eu vou ruir". Eu estou em pé, mas tendo ao horizontal.

LF: "Estou fazendo aqui um esforço, estou aqui me encostando nas paredes" porque é um trabalho que precisa de paredes.

JM: Mas tem aquela montagem no chão também. É isso que eu acho bom, você não sabe o que está estruturando o quê. Quanto o tecido segura aquelas formas e o gesso ao contrário.

LF: Ele é muito plástico mesmo. Em geral, você trabalha o gesso com sisal, isso permite que ele quebre, mas não desmonte. Com todas as rachaduras, eles continuam... É um trabalho que depende da instalação, dos gestos, do corpo, de levar, apoiar, equilibrar, ele pode ficar sempre um pouco diferente. É uma negociação entre corpos. 
FP: Você falou de arquitetura, e acho que tem essa relação com abrigo, acolhimento, mas você falou do Beuys e do Morris, desse casamento, mas acho que tem muito do Tunga aí, das Instaurações.

MM: O Walter Firmo fala, porque você falou uma coisa agora e eu lembrei: "a emoção da fotografia está no poder do risco". Eu adorei ele falar do poder do risco. Ele poderia ter falado no poder do erro. Ele poderia ter dito "risco do erro" ou "possibilidade do erro". E aí eu fiquei pensando, quando eu li, lembrei das suas coisas, até onde isso é um jogo interno do seu trabalho.

LF: É o erro constitutivo do trabalho. Fora a ideia de errar.

MM: Você tem isso, esse endereçamento? Por exemplo, nos trabalhos com filmes, você se coloca como dispositivo de captura e depois responde aos instantes em que a sua atenção foi capturada, retornando para fotografia...

LF: Quando eu eventualmente retorno, já não é mais aquilo que foi quando eu passei ou quando eu filmei. Essa cidade em movimento continua com seu movimento, a fotografia vai ser mais uma fixação de um breve momento.

MM: Talvez esse jogo do poder do erro seja algo da instalação, da montagem. Para trazer o trabalho para o espaço expositivo, seja lá qual for.

LF: Talvez tenha a ver com uma negociação entre acabamento e inacabamento, porque ao mesmo tempo são trabalhos que podem ser repetidos, mas sempre serão diferentes. Eu posso continuar, eu adoraria poder continuar fazendo isso. É um esquema básico, muito simples. São duas estacas e um cobertor e é isso que dá muitas possibilidades de arranjo, de configuração no espaço. Mas toda essa série [Trabalho de greve] nasce de um desejo de pintura, e de desenho também. Eu queria intervir na superfície do cobertor com tinta branca, e de fato eu comecei por aí. Para pintar, fui criando mecanismos para conseguir submergir partes dos cobertores na tinta, e aí a tinta chamou o gesso, se tornou sólida, estruturante. Foi essa construção de mecanismos de pintura que trouxe o gesso.

JPQ: E tem a produção de uma série, que também é uma questão da pintura.

MM: Agora que você falou do mergulhar, tem também aquele outro trabalho que se chama Pás, que você mergulhou o tecido ou o papel no óleo e guardou.

LF: Pintura por imersão. Não é uma pintura que você vai lá com pincel, mas que você submerge, impregna o material.

MM: Você quer falar um pouco desse trabalho (apontando para o livro, páginas 6-9), porque eu não conhecia. 


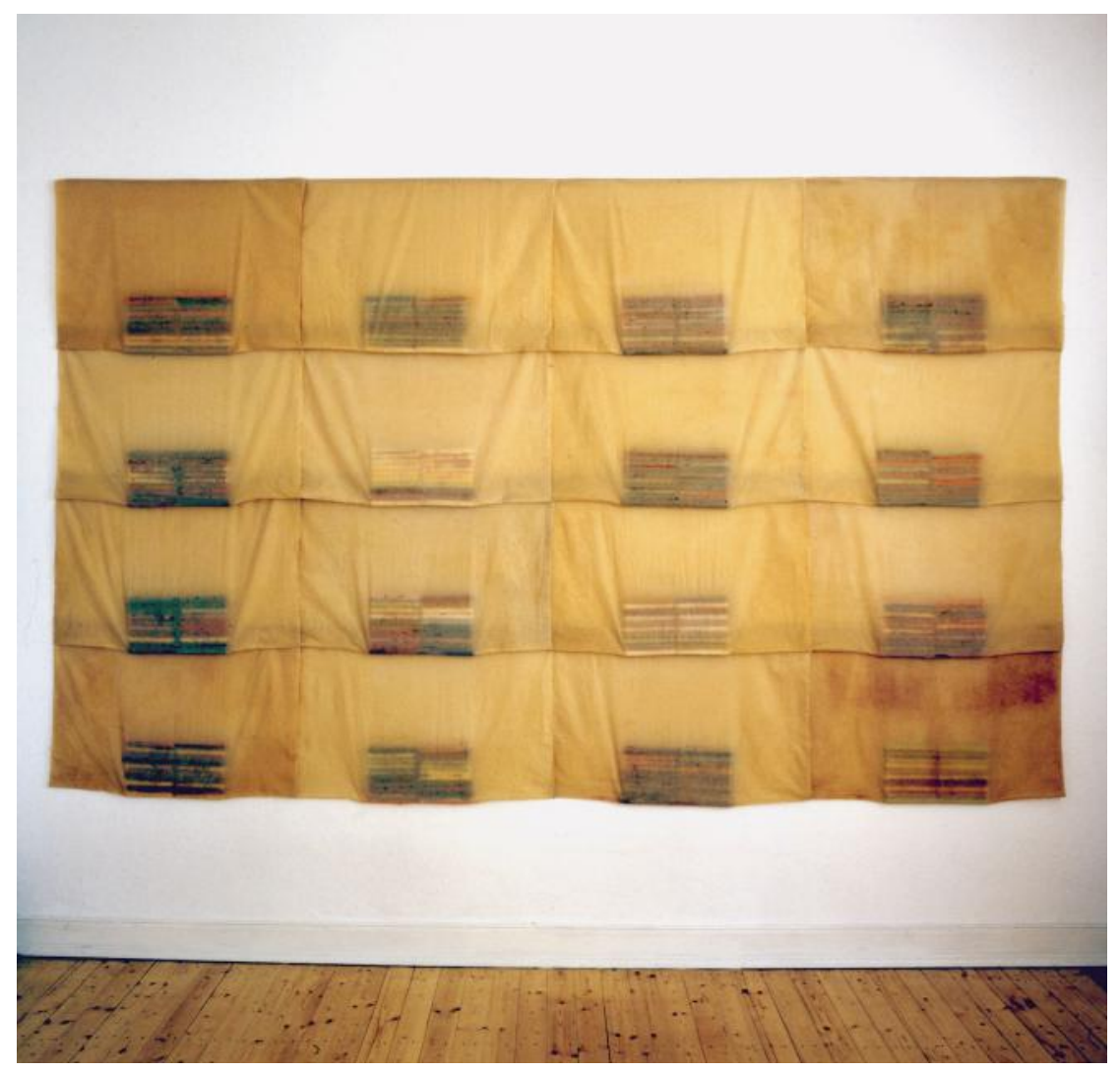

Body-bags, 1991

Óleo de linhaça sobre tecido, velas coloridas, $340 \times 210 \mathrm{~cm}$

Foto: Egbert Trogemann

LF: Essa construção que arruína, essa dinâmica da ruína está muito presente no trabalho nessa exposição mais recente. $\mathrm{O}$ tempo se traduz como fragilidade, vulnerabilidade.

MM: Que é o destino nacional, você passa da promessa para a ruína, sem nada no meio. JPQ: Mas ainda assim, ele tem presença em relação aos outros trabalhos. Ele se anuncia mais no espaço.

JM: Sim, é verdade.

LF: Apesar de ser mole, ele tem uma robustez.

JPQ: E também vai deitado.

MM: Ele é monumental, mas é irônico da monumentalidade. Ele já se anuncia como ruína: “eu vou ruir". Eu estou em pé, mas tendo ao horizontal.

LF: "Estou fazendo aqui um esforço, estou aqui me encostando nas paredes" porque é um trabalho que precisa de paredes. 
JM: Mas tem aquela montagem no chão também. É isso que eu acho bom, você não sabe o que está estruturando o quê. Quanto o tecido segura aquelas formas e o gesso ao contrário.

MM: Eles têm alguma coisa dentro?

LF: Não, não têm nada dentro. Fiz esses envelopes para uma segunda versão de Bodybags, que nunca realizei. Mas ficaram guardados e os utilizei em Pás.

MM: E essa parte mais escura?

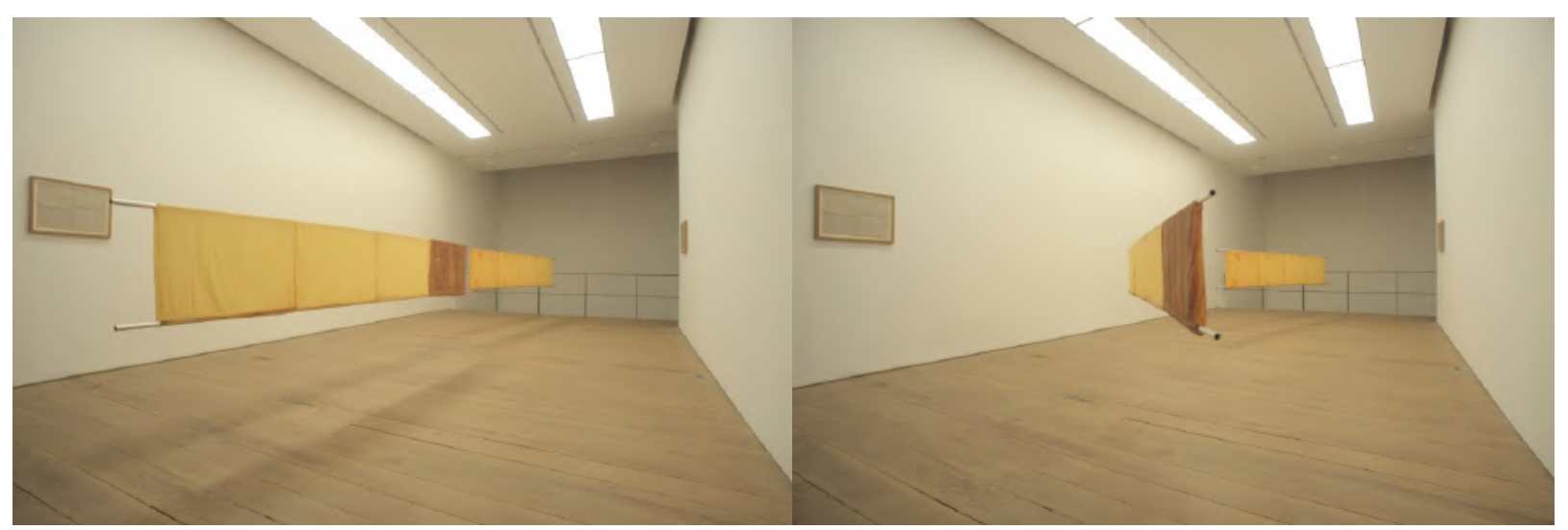

Pás, 1991-2012

Tecido embebido em óleo de linhaça, alumínio e fio de nylon, 4,00 x 0,60 x 0,02 m

Galeria Progetti, Rio de Janeiro

Fotos: Wilton Montenegro

LF: Isso aqui ainda está clarinho porque ele ficou enrolado, guardado, e essa parte mais escura é a parte mais externa que foi absorvendo a luz. Com o tempo e com a exposição à luz, o tecido embebido em óleo vai escurecendo.

FP: Aquele anterior, o Bodybags, é o Como fazer cinema sem filme. O que você mostrou anteriormente, aquele que você produziu na Alemanha. O padrão gráfico, as transparências, tem uma coisa de revelação.

LF: Tem esse interesse. Tem esse aqui também [Potências], esse não tem cor, esse é todo amarelo, do próprio papel também mergulhado em óleo.

JPQ: Esse vira livro. São lindas essas imagens. E elas estão em um regime estético muito atual, são imagens que têm uma intimidade, o que corresponde com essa produção de imagem atual, do fotografar tudo a todo tempo. São fotografias de coisas que você está vendo em casa, a janela, o espelho. É legal essa passagem para o livro, que é um procedimento comum dos anos noventa também.

LF: Na verdade foi uma maneira de ter um registro daquela produção e de organizá-la, porque esses livrinhos em xerox eu fiz já quando estava para voltar para o Brasil. Algumas peças vieram,

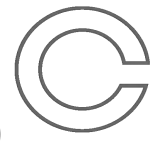


outras foram deixadas lá, outras se perderam. Isso [Daywork, Nightwork] era no ateliê que dividia com o Carlito e com o Zé.

JPQ: Mas você não volta a essas imagens como registro do trabalho. É uma outra forma de registro que já é em si o trabalho atuando dentro de uma lógica autorreferente. Tem um repertório mais alargado, de imagens, mais ambientais também.

LF: Não tinha muita essa preocupação com a documentação. Sim, estava ali registrando o trabalho mas eram momentos do trabalho e são dois cadernos, um fotografado de dia [Daywork] e o outro fotografado à noite [Nightwork]. São luzes diferentes, o da noite fica todo amarelo.

FP: É interessante que a palavra trabalho apareça, como uma rotina.

JPQ: É o que o João está capturando... Ela está fotografando o ateliê como trabalho e não o trabalho que foi produzido no ateliê.

FP: Esse cotidiano, essa rotina prosaica.

MM: Uma imersão na vida que ela tinha ali. Como levar a vida que tenho aqui para lá.

LF: Era um momento em que o Carlito e o Zé já tinham voltado para o Brasil, eu estava sozinha no ateliê com todo o espaço, também já encaixotando.

MM: Como foi essa volta?

LF: Eu acho que o primeiro impacto da chegada aqui, equivalente ao impacto da chegada lá, resultou nisso daqui: Pedras Candelária.

JM: Tinha acabado de acontecer o massacre.

LF: Tinha acabado de acontecer o massacre da Candelária e depois o de Vigário Geral. Que virou um trabalho que se perdeu. Eu tenho imagens dele, mas são precárias.

JPQ: Ou seja, você estava impactada pela violência urbana carioca dos anos noventa.

LF: Foi esse o choque, depois de nove anos na Alemanha.

JPQ: Esses registros de violências.

LF: Teve uma época em que eu trabalhava na Deutsche Welle fazendo tradução. Era um tempo em que não havia internet e lá chegavam os jornais. Eu me lembro de ver um deslizamento de terra, em uma favela em Minas, por causa das chuvas. Eu me lembro da imagem, do impacto que 

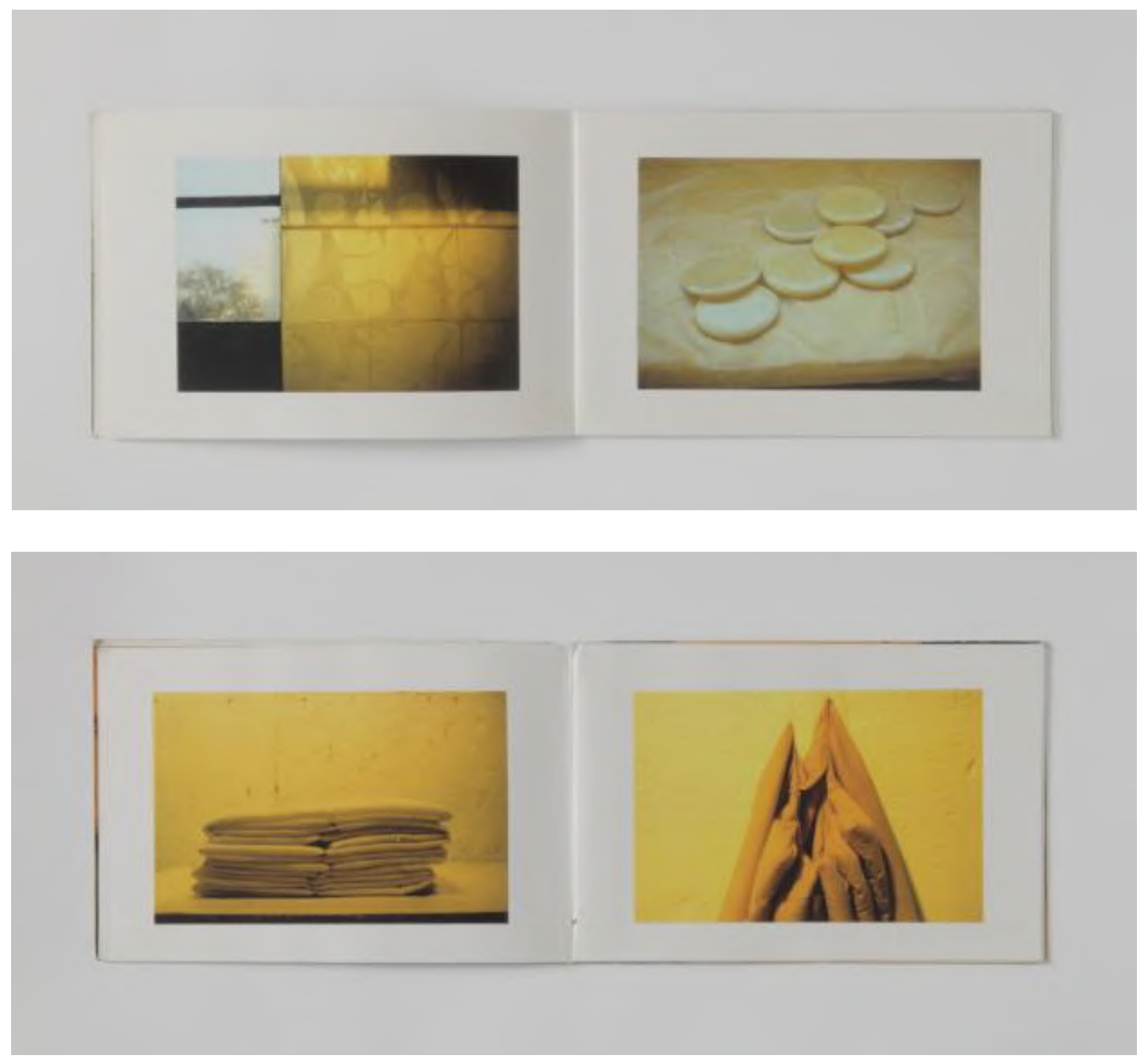

Daywork/Nightwork

Livro em xerox colorida

$12 \times 18 \mathrm{~cm}$

Fotos: Wilton Montenegro

ela me causou. Eu acho que essa coisa da violência a gente carrega, mesmo morando em um país que não tenha esse nível de violência que tem aqui, esse embate, essa convivência assim tão próxima. Eu me lembro de sonhos em que essa violência aparecia assim como uma memória recalcada, muito profunda.

MM: Tem muita coisa como nação que ainda não resolvemos. O Caetano fez há pouco uma declaração que terminou de um jeito maravilhoso: "— isso é medo da responsabilidade civilizatória".

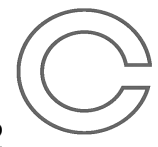


LF: Só pra terminar, já que a gente falou de violência... Eu espero que a gente consiga assumir essa responsabilidade civilizatória. (Apontando para o trabalho Sem título, 2018, publicado no catálogo ilha 03, p. 2).

AC: É engraçado porque seu trabalho tem essa condição de rua, essa horizontalidade. Os cobertores, esse cantinho, essa encruzilhada.

MM: Me fale do cantinho, esse rodapé existia no lugar ou você inventou?

LF: Não, o trabalho na verdade é só essa bacia. Com urucum e com óleo de linhaça. Tem essa relação com a pintura a óleo, de novo esse processo do pigmento e do óleo. Eu acho que estou entendendo cada vez mais esse trabalho. Foi um trabalho que apareceu no meio do processo da exposição, eu não sabia muito bem se era trabalho, se não era, se era meu, se não era. Que trabalho era esse? Mas ele está ficando cada vez mais claro para mim. Isso recuperando uma memória muito, muito antiga, que é a memória de um sonho da infância na ditadura. Enfim, de uma imagem aterrorizante para mim, que era apenas a imagem de uma bacia cheia de sangue, só que isso é transmutado através do urucum.

AC: Mas você lembrou desse sonho agora?

LF: Não, eu já estava lembrando dele na época da exposição. Ele está aí nesse meio termo, entre uma imagem e um Cine-sonho, que são memórias de sonho escritas no papel carbono, que se transformam em projetos de filme. Mas aqui ele reaparece como imagem concreta que evoca todas essas projeções. Ele não constava nem da ficha técnica dos trabalhos. Era um trabalho ainda se fazendo, mas ao mesmo tempo via essa coisa ali naquela casa, tinha que ter essa cor, essa bacia de cor vermelha na exposição. Lembro que o Lepecki falou: "eu acho que está errada a legenda", porque junto com os Cine-sonhos, tinha o Carne moída, que era um trabalho também de escrita sobre papel carbono. Ele olhou para a bacia e achou que era carne moída, que é também um pouco dessa ordem de emergência da violência. Carne moída é de novo essas coisas que passam pela gente, foi uma van que eu vi passar com um adesivo escrito carne moída. E não tem filme que dê conta disso. A bacia de urucum por enquanto está sem título, talvez permaneça para sempre sem título.

AC: Você pintou o rodapé, então?

LF: Não, o rodapé é da casa. O importante é que era um canto, um canto da entrada.

MM: É um rodapé enlutado, parece aqueles cartões de luto.

LF: Você entrava pela porta e... Era macumba mesmo.

AC: Era uma oferenda.

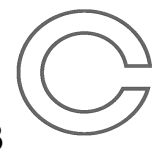


Concinnitas | v.20, n.36, dezembro de 2019

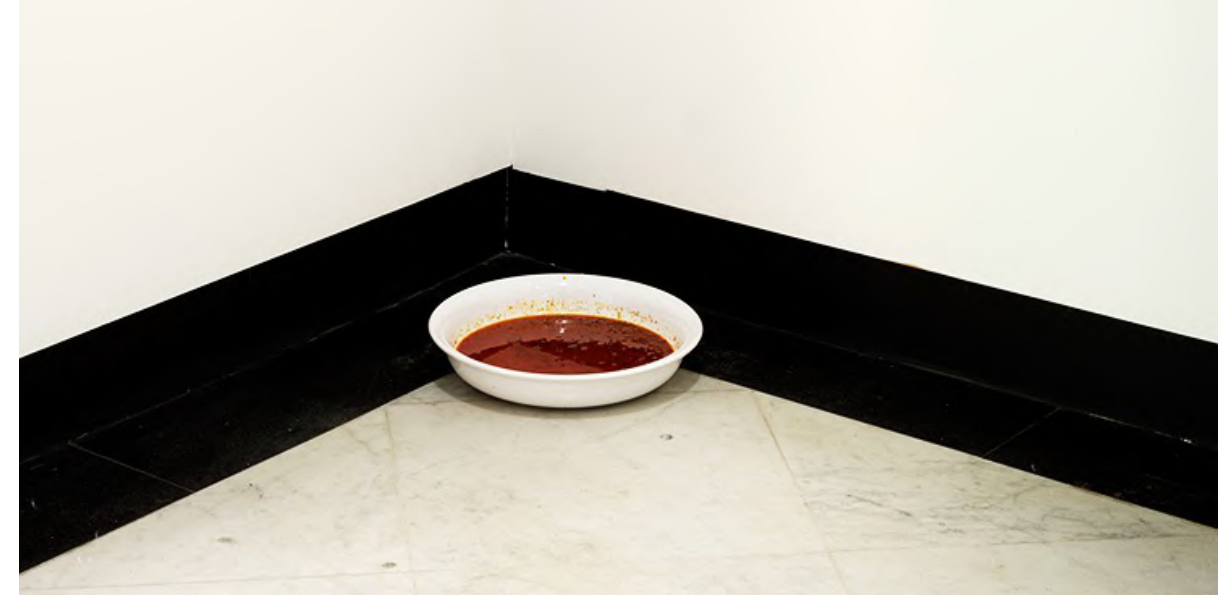

Sem título, 2018

Urucum e óleo de linhaça, prato de cerâmica

Ø $40 \mathrm{~cm} \times 6 \mathrm{~cm}$

ilha 03: Livia Flores, Projeto FOZ/Z42, Rio de Janeiro

Foto: Pat Kilgore 
FP: Foi o trabalho que a gente usou no convite para lançar a chamada de colaborações para esse número da revista.

LF: Por isso achei que tinha que falar dele.

JPQ: E, para mim, o urucum ainda reverbera o massacre indígena, como marca de uma repetição histórica e de um contínuo que volta, que reaparece. Não sei como esse elemento aparece para você, mas acho que é um mecanismo para reverenciar a História Social, que aparece também no trabalho no Museu de Petrópolis e nos cobertores de rua.

MM: Processo libertatório.

JPQ: Exatamente.

FP: Que tem a ver com o massacre de Vigário Geral, da Candelária, aí penso também no Carandiru da Lygia Pape.

AC: As Trouxas do Barrio, também.

FP: A própria ideia de carne moída.

LF: Para mim, é essa história que os tacos carregam, que os cobertores carregam, não apenas como cobertor de morador de rua, mas também como cobertores que se constituem por infinitas peças de roupas que algum dia já foram usadas, essa reciclagem como uma espécie de história invisível, que está ali inscrita nesses materiais coletivos.

MM: É que na verdade a História é isso, transforma a gente num filtro, a gente é essa mistura, de todos os resíduos das coisas não resolvidas, quando não assumimos a tal responsabilidade civilizatória, isso não se resolve, não avança, somos todos nós.

LF: É a autofagia.

FP: São os fantasmas que ficam olhando, que voltam, e reassombram a gente.

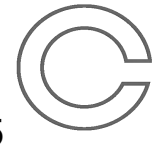

